\begin{tabular}{|l|l|}
\hline $\begin{array}{l}\text { 2. To: (Receiving organization) } \\
\text { Distribution }\end{array}$ & $\begin{array}{l}\text { 3. From: (originating Organization) } \\
\text { Immobilized Waste }\end{array}$ \\
\hline $\begin{array}{l}5 . \text { Proj-/Prog./Dept./Div.: } \\
\text { W-520 }\end{array}$ & $\begin{array}{l}\text { 6. Design Authority/ Design Agent/Cog. } \\
\text { Engr.: }\end{array}$ \\
\hline
\end{tabular}

8. Originator Remarks:

Immobilized Low-Activity Waste Disposal Facility, Project $W$ 520 CDR and PSE Statment of Work

11. Receiver Remarks: 11A, Design Basel ine Document? [] Yes [X] No
4. Related EDT NO.:
N/A

7. Purchase Order No.:

N/A

9. Equip./Component No.: N/A

10. System/Bldg./Facility: N/A

12. Major Assm. Dwg. No.: N/A

13. Permit/Permit Application No.: N/A

14. Required Response Date: N/A

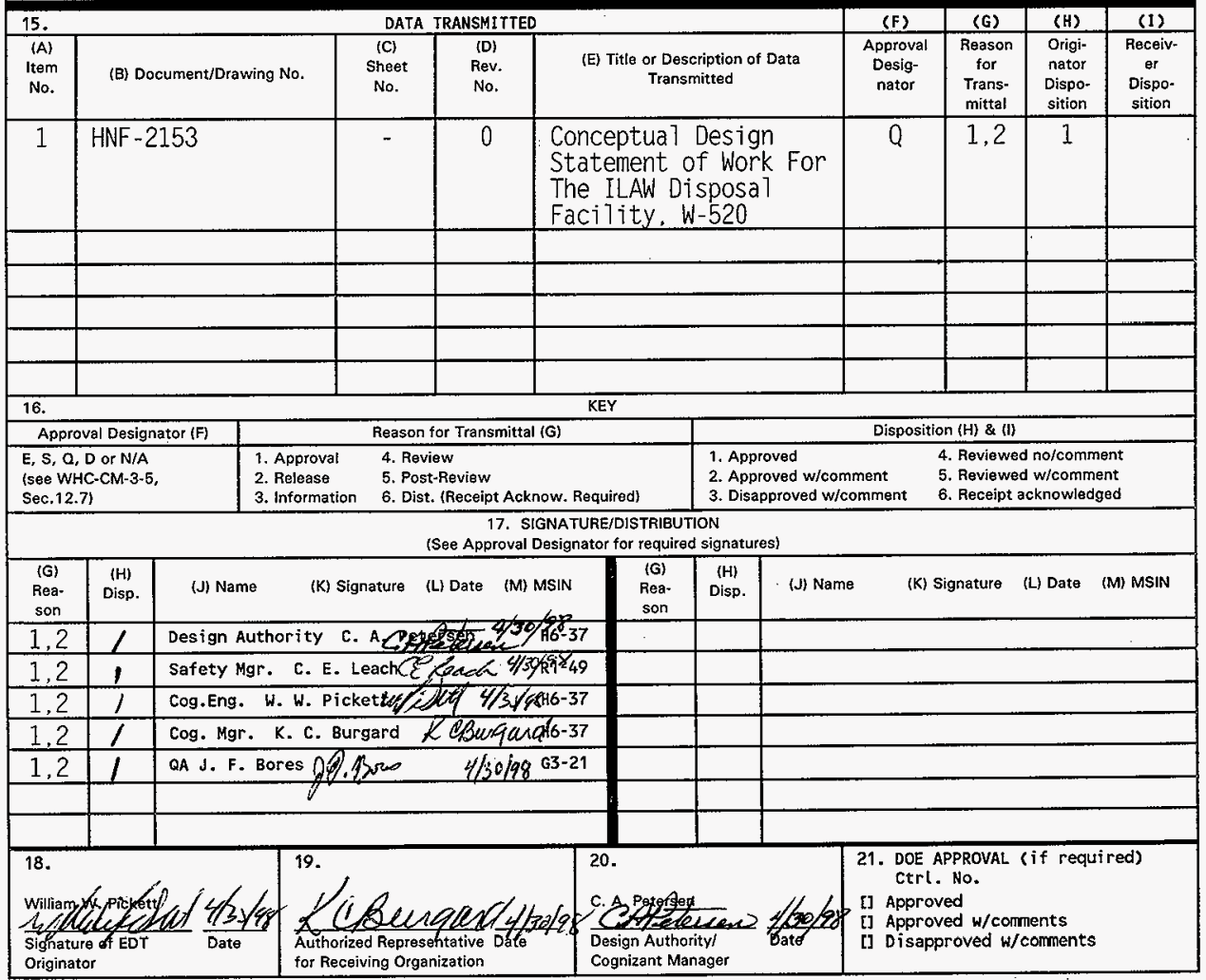




\section{Conceptual Design Statement of Work For The Immobilized Low-Activity Waste Disposal Facility, Project W-520}

William W. Pickett

FDNW, Richland, WA 99352

U.S. Department of Energy Contract DE-AC06-96RL13200

EDT/ECN: 624113

Org Code: 73000

UC: 721

B\&R Code: EW3130010

Charge Code: D4DNR

Tota1 Pages:

51

Key Words: Immobilized Low-Activity Waste Disposal Project

Abstract: This Statement of Work outlines the deliverables and schedule for preparation of the Project $W-520$ Conceptual Design Report, including, work plans, site development plan, preliminary safety evaluation, and conceptual design.

TRADEMARK DISCLAIMER. Reference herein to any specific comercial product, process, or service by trade name, trademark, manufacturer, or otherwise, does not necessarily constitute or imply its endorsement, recommendation, or favoring by the United States Government or any agency thereof or its contractors or subcontractors.

Printed in the Unired States of America. To obtain copies of this document, contact: Document Control Services, P.0. Box 950, Mailstop 46-08, Richland WA 99352, Phone (509) 372-2420; Fax (509) 376-4989.
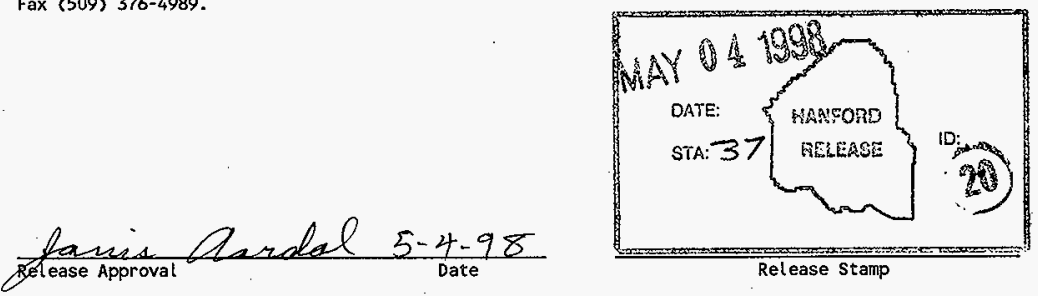
HNF-2153, Rev. 0

\section{CONCEPTUAL DESIGN STATEMENT OF WORK FOR THE IMMOBILIZED LOW-ACTIVITY WASTE DISPOSAL FACILITY}

\section{PROJECT W-520}

April 28, 1998

Prepared for

U.S. Department of Energy

Richland, Washington 
HNF-2153, Rev. 0

Project Hanford Management Contractor Technical Representative Approvals

Document Title: Conceptual Design Statement of Work for the Immobilized Low-Activity Waste Disposal Facility, Project W-520

Reviewed by: C. A. Petersen, Numatec Hanford Corporation

Richland, Washington

Reviewed by:

C.P. Leadh

C. E. Leach, Manager (TR PSE) Operations and Project Safety Support

TWRS Nuclear Safety \& Licensing

Duke Engineering and Services Hanford

Richland, Washington

Approved by:

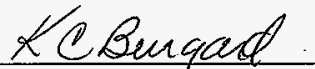

K. C. Burgard, Project Manager (TR CDR)

Immobilized Low-Activity Waste

Disposal Facility

Lockheed Martin Hanford Corporation

Richland, Washington $\frac{4 / 30 / 98}{\text { Date }}$

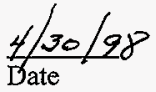

Date 


\section{CONTENTS}

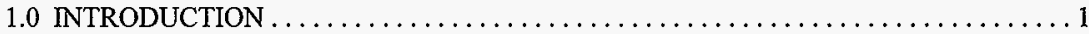

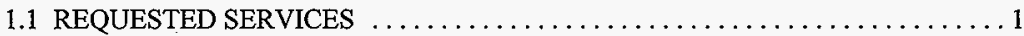

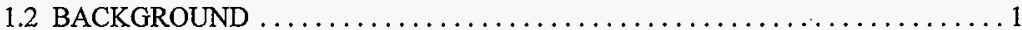

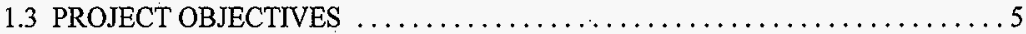

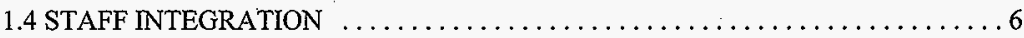

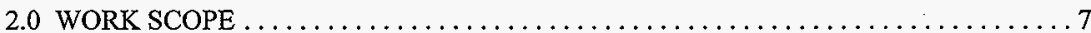

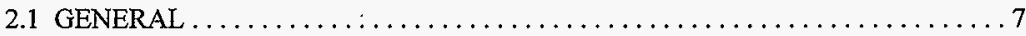

2.2 DESIGN RESPONSIBILITY $\ldots \ldots \ldots \ldots \ldots \ldots \ldots \ldots \ldots \ldots \ldots \ldots \ldots \ldots$

2.3 DESIGN REPORT REQUIREMENTS $\ldots \ldots \ldots \ldots \ldots \ldots \ldots \ldots \ldots \ldots \ldots \ldots$

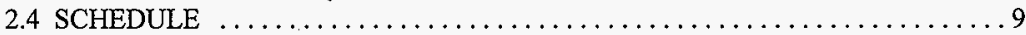

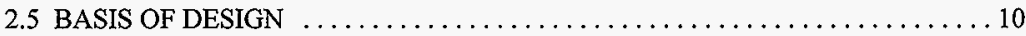

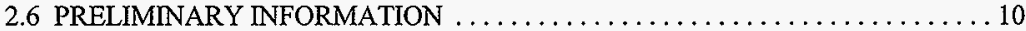

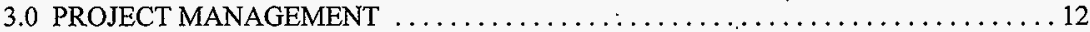

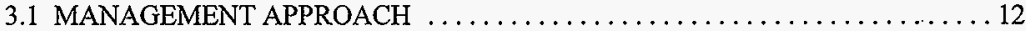

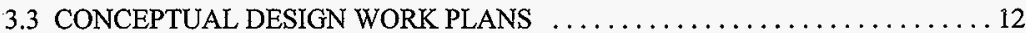

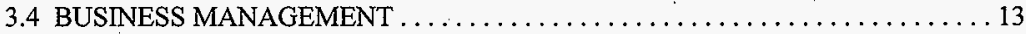

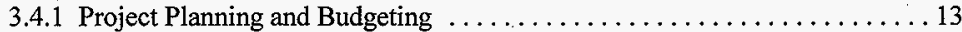

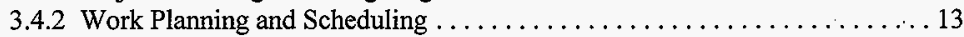

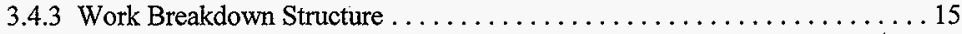

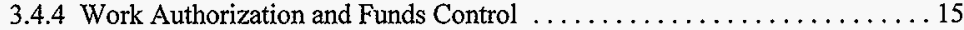

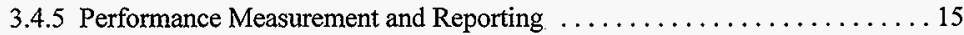

3.4.6 Management Reports, Meetings, and Reviews ................. 16

3.5 DOCUMENT REQUIREMENTS . . . . . . . . . . . . . . . . . . . . 19

3.5.1 General Data ..................................... 19

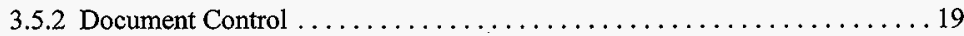

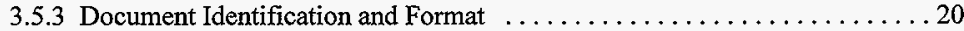

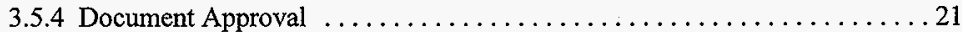

3.5.5 Document Transmittal . . . . . . . . . . . . . . . . . . . . . 21

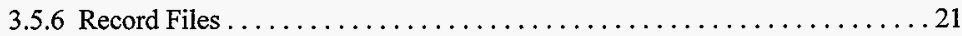

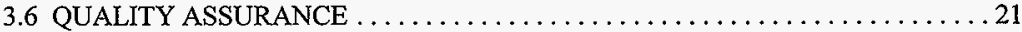

3.6.1 Accessibility for Assessment Purposes . . . . . . . . . . . . . . . 22

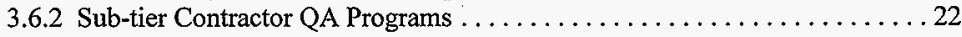

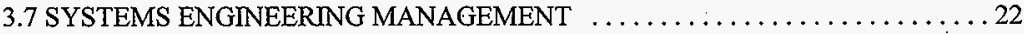

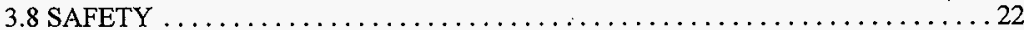

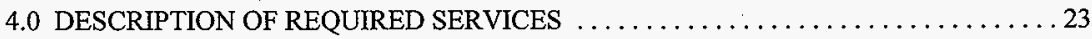

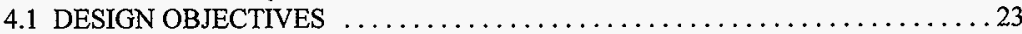

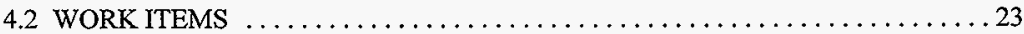

4.2.1 Design Media Transmittal . . . . . . . . . . . . . . . . . . . 31

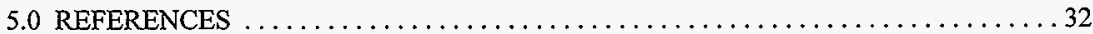

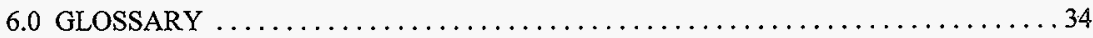




\section{HNF-2153, Rev. 0}

\section{FIGURES}

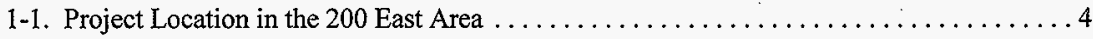

\section{TABLES}

1-1. Tank Waste Remediation System Phase I \& II Program Schedule $\ldots \ldots \ldots \ldots \ldots \ldots . \ldots . \ldots$

1-2. Major W-520 ILAW Disposal Project Activities Schedule $\ldots \ldots \ldots \ldots \ldots \ldots \ldots \ldots$

2-1. Summary List of Deliverables to Support Validation Process. ................ 9

2-2. Conceptual Design Deliverable Schedule ........................... 10

3-1. Project Summary Work Breakdown Structure. ........................ 14

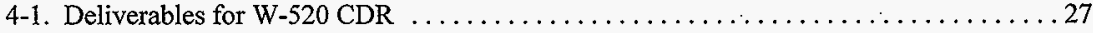


HNF-2153, Rev. 0

\section{CONCEPTUAL DESIGN STATEMENT OF WORK FOR THE IMMOBILIZED LOW-ACTIVITY WASTE DISPOSAL FACILITY, PROJECT W-520}

\subsection{INTRODUCTION}

\subsection{REQUESTED SERVICES}

This Statement of Work (SOW) describes the work scope to be performed by the ArchitectEngineer (A-E), under the direction of the Project Hanford Management Contractor Technical Representatives (TR). Specifically, the A-E shall prepare a conceptual design (CD) for the Immobilized Low-Activity Waste (ILAW) Disposal Facility. The A-E consists of Fluor Daniel Northwest (FDNW) as the primary design agent.

The CD work scope covers the initial design phase of the ILAW Disposal Facility Project. This initial design phase entails services for CD development and issuance of the conceptual design report (CDR) and the Preliminary Safety evaluation (PSE) for the ILAW Disposal Facility. The CD effort will encompass definition of new installations.

In parallel to the ILAW Disposal Facility Project CD development, a Tank Waste Remediation System (TWRS) privatization activity, contracted separately by the U.S. Department of Energy (DOE), is in progress. Input from this activity will be incorporated into the CD as appropriate.

\subsection{BACKGROUND}

As part of the TWRS Program, the DOE has embarked upon a course to acquire Hanford Site tank waste treatment and immobilization services using privatized facilities (i.e., privately developed, financed, constructed, owned, operated, decontaminated, decommissioned, and closed [RL 1996]). Successful bidder(s) (i.e., vendor or team of vendors awarded a contract) are to be paid for the immobilized Hanford Site tank waste (product) after it is produced, thereby recouping their investment. This plan contains a two-phased approach. Phase I is a proof-of-principle and commercial demonstration-scale effort and Phase II is a full-scale production effort. Details of the TWRS Phase I and Phase II Program schedule are shown in Table 1-1. Table 1-2 details the W-520 ILAW Disposal Project Activities Schedule.

In accordance with the solicitation of Phase I services, transportation and disposal of various products from the demonstration plants and ultimately the production plants (e.g., immobilized high-level waste [HLW], ILAW, separated cesium, etc.) are to be furnished by RL. The TWRS Environmental Impact Statement Record of Decision (62 FR 8693) states that ILAW will be disposed on site in a near surface disposal facility. Therefore, a facility for disposal of ILAW must be provided. The recommended path forward (Burbank 1997) for ILAW disposal provides a suite of disposal unit design solutions that meet requirements dictated by the differing characteristics of the ILAW waste that may be received from the tank waste treatment vendors. 
Table 1-1. Tank Waste Remediation System Phase I \& II Program Schedule.

\begin{tabular}{|c|c|c|}
\hline Activity & From & To \\
\hline \multicolumn{3}{|c|}{ Phase I Proof-of-Principal Demonstration } \\
\hline Minimum order quantity operations & June 1,2002 & June 1,2007 \\
\hline Extension operations & $\begin{array}{l}\text { Completion of } \\
\text { maximum order } \\
\text { quantity }\end{array}$ & June 1,2011 \\
\hline \multicolumn{3}{|c|}{ Phase II Full-Scale Production } \\
\hline Award contract & 2005 & -- \\
\hline Design, permitting/licensing, construction & 2005 & 2013 \\
\hline Operations & 2013 & 2028 \\
\hline Decontamination and decommissioning & 2028 & 2033 \\
\hline
\end{tabular}

Table 1-2. Major W-520 ILAW Disposal Project Activities Schedule.

\begin{tabular}{|l|c|c|}
\hline Critical Decision 1 (Initiate Conceptual Design) & $1 / 2 / 98$ & $2 / 2 / 98$ \\
\hline Conceptual Design & $2 / 2 / 98$ & $12 / 15 / 98$ \\
\hline Advanced Conceptual Design & $12 / 16 / 98$ & $9 / 29 / 00$ \\
\hline Critical Decision 2 (Initiate Design) & $12 / 1 / 00$ & $2 / 1 / 01$ \\
\hline Preliminary Design (Title I) & $2 / 1 / 01$ & $5 / 31 / 01$ \\
\hline Preliminary Safety Analysis Report (Title I) & $2 / 1 / 01$ & $5 / 31 / 01$ \\
\hline Detailed Design (Title II) & $6 / 1 / 01$ & $9 / 30 / 02$ \\
\hline Preliminary Safety Analysis Report (Title II) & $6 / 1 / 01$ & $9 / 30 / 02$ \\
\hline Critical Decision 3 (Initiate Construction) & $10 / 1 / 02$ & $10 / 2 / 02$ \\
\hline Construction & $4 / 1 / 03$ & $9 / 30 / 04$ \\
\hline Final Safety Analysis Report & $4 / 3 / 03$ & $8 / 14 / 04$ \\
\hline Critical Decision 4 (Begin Hot Operations) & $10 / 1 / 04$ & $3 / 31 / 05$ \\
\hline Operations & $8 / 2 / 05$ & $8 / 1 / 11$ \\
\hline
\end{tabular}

The strategy includes a series of manageable projects that: (1) provide the common disposal system support facilities, equipment, and infrastructure, (2) deploy multiple modular disposal units tailored to specific ILAW waste characteristics, and (3) design and construct surface barrier closure systems to minimize or prevent intrusion by water, humans, plants, and animals. This strategy provides ILAW disposal capacity on a time phased a schedule with the flexibility to adjust the number and type of modular disposal units based on operating experience and/or changes in the requirements for ILAW disposal. Project W-520 includes construction of the common disposal system support facilities, equipment, and infrastructure; the first two disposal modules; and design of the closure system to support a performance assessment of the facility. The remaining ILAW disposal modules will be implemented as subsequent projects, as will the closure system. The two W-520 disposal modules will be sized to provide a slight excess of 
storage space to accommodate the balance of Phase I ILAW products to be generated after the Project W-465 ILAW Storage Facility is filled to capacity. This excess capacity is included as contingency to accommodate uncertainties in the estimated Phase I immobilization output. Subsequent disposal modules will be constructed to keep pace with Phase II production rates.

A disposal location on 90 acres of uncontaminated, vacant land southwest of the PUREX plant in the 200 East Area has been identified in the Tank Waste Remediation System Complex Site Evaluation Report, WHC-SD-WM-SE-021, Rev. 0. Figure 1-1 shows the project location in the 200 East Area.

Until the Phase I Privatization Vendors are chosen and specify ILAW package characteristics, the DOE prescribed product specifications require sealing the ILAW in steel packages with nominal dimensions of $1.8 \mathrm{~m}$ long $\times 1.2 \mathrm{~m}$ high $\times 1.2 \mathrm{~m}$ wide. Each package can weigh no more than $10,000 \mathrm{~kg}$ and have a maximum allowable surface dose rate of 1,000 $\mathrm{mrem} / \mathrm{hr}$. The waste packages must meet the requirements for shallow land disposal in the state of Washington. For the Project W-520 disposal modules, the packages will be placed in underground concrete vaults with remote handling equipment, radiation shielding, and a surface weather cover.

The space between the ILAW packages and the disposal modules will be backfilled with filler material to eliminate void space, and a cover added to vaults containing remote-handled waste. At closure, a protective barrier will be constructed over the disposal units to inhibit moisture infiltration, minimize transport of contaminants to the ground water, and mitigate the effects of intrusion from plants, animals, and humans.

Disposal modules for ILAW will be deployed on a time phased basis through a series of construction projects. Initial program planning has these scheduled at roughly three year intervals. This schedule provides enough lead time to obtain funding for construction of additional modules while avoiding the commitment of a large investment in a particular design solution. Design features of the disposal modules will be tailored to meet only the specific requirements of a particular waste's characteristics. The two Phase I modules will operate concurrently to provide the required throughput rate. For Phase II production, the approach provides for multiple disposal modules operating concurrently to more easily handle the expected throughput of up to 27 packages per day. The last project, at the conclusion of Phase II, will decommission the operations buildings and construct the final closure barrier over the disposal site. 
HNF-2153, Rev. 0

Figure 1-1. Project Location in the 200 East Area.

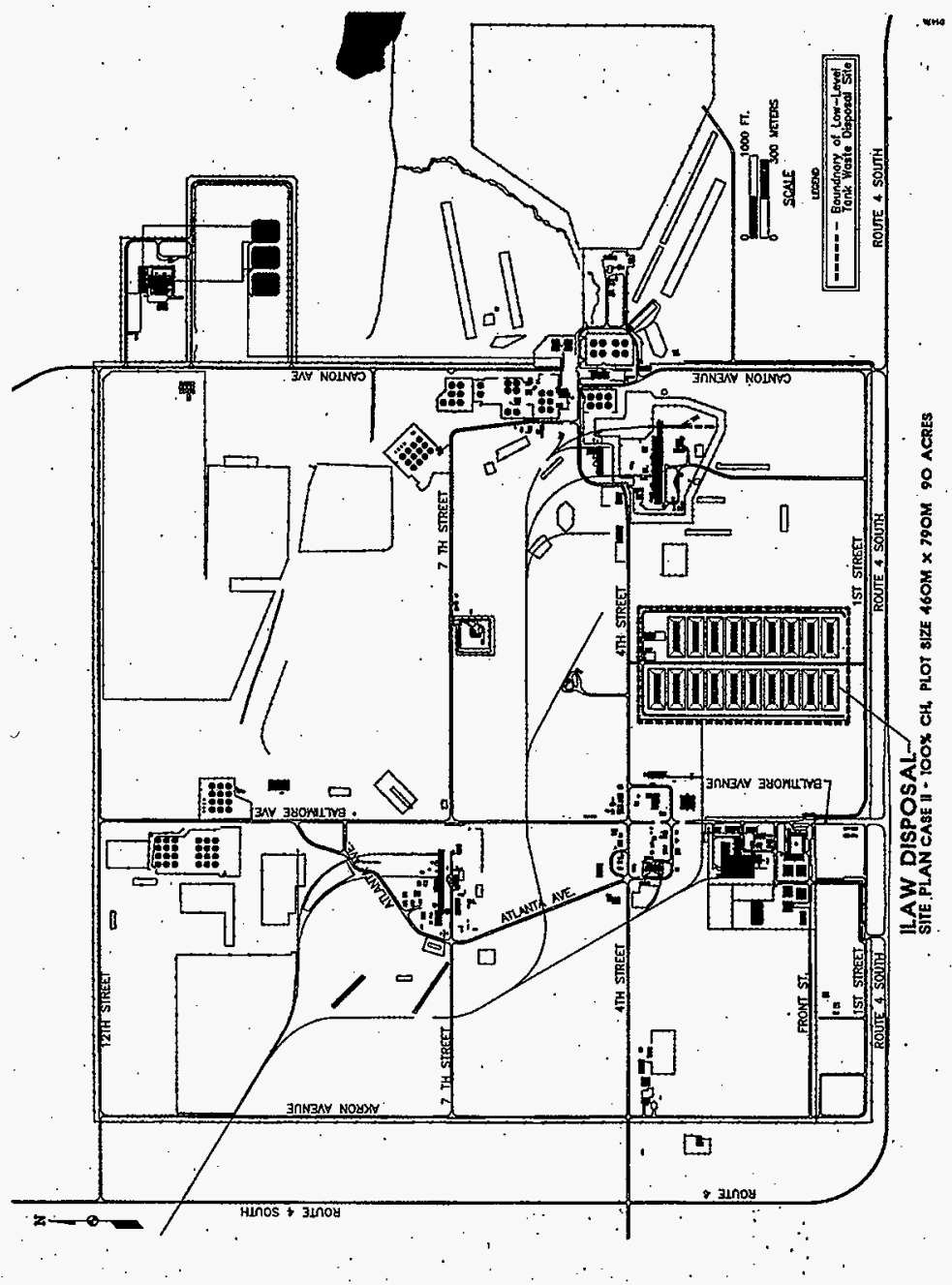




\subsection{PROJECT OBJECTIVES}

This SOW outlines the products required by LMHC, and ultimately RL, to develop a conceptual design and cost basis for the validation of a year 2000 Line Item project to install new facilities to receive the certified ILAW packages produced by the private contractors and dispose of the packages in a manner that does not preclude retrieval. The scope of the W-520 Project is to provide sufficient disposal capacity for the remaining Phase I ILAW product after the W-465 Project facility (retrofitted grout vaults) is filled to capacity. Subsequent disposal capacity required for Phase II production will be provided by follow-on projects. In addition to providing disposal capacity for Phase I ILAW product, the W-520 Project will provide the required infrastructure for all remaining ILAW (Phase I and Phase II) disposal (road access, electrical service, etc.). The conceptual design for the W-520 Project includes a conceptual closure design for all modules (including the W-465 ILAW storage facility), although definitive design and construction of the closure system are not a part of the Project W-520 scope.

This project can be broken into the following subsystems:

- Disposal Modules

- Vaults

- Liner/Leachate collection system

- Material Handling Systems

- Cranes

- Fork Lifts

- Voidspace Infill Equipment

- Transportation

- Transporters

- Shielded Containers

- Support Structures

- Control Room

- Change Rooms

- Maintenance Facility

- Telecommunications/Automated Data Processing (ADP)/Accountability

- Infrastructure

- Road Access

- Electrical

- Water

- Fire

- Sanitary

- Sewer

- Parking

- Lighting

- Fencing

- Communications Systems 
HNF-2153, Rev. 0

- Conceptual Design for Closure System applicable to W-520 \& W-465 vaults

- Other Project and On Sight Services Interface Definition

- Maintenance Services

- Transportation

- Leachate Collection

- RCRA Monitoring (groundwater)

\subsection{STAFF INTEGRATION}

The CD work scope described in this SOW requires a strong interface with other Hanford Site programs and activities. To achieve an effective integration of all project participants (including the TRs and U.S. Department of Energy, Richland Operations Office [RL] personnel), key FDNW personnel and a significant majority of their technical staff shall be located in the Tri-Cities, Washington. This arrangement will facilitate the total project team integration and allow efficient input of technical information during the CD effort. 
HNF-2153, Rev. 0

\subsection{WORK SCOPE}

FDNW is fully responsible and accountable for the work performed under this SOW. This work scope includes administrative responsibilities, coordination and development of all design drawings, cost estimates, schedules, technical reports, calculations, a Preliminary Safety Evaluation (PSE), and other $\mathrm{CD}$ services as outlined in this SOW. All design services and technical work required to produce acceptable design media shall meet quality standards and shall comply with all applicable criteria, such as federal and state regulations, industry standards, and the TR's requirement documents, including this SOW and the Design Requirements Document (DRD) for Project W-520, ILAW Waste Disposal (Burbank 1998). Deliverables shall be compatible with the TWRS Configuration Management Plan, HNF-1900.

\subsection{GENERAL}

FDNW shall perform the CD in a manner consistent with project objectives, technical scope, budget, and schedule. The CD shall be developed in sufficient detail to establish the overall project scope, design features, and concepts including: process; mechanical; electrical; heating, ventilating, and air-conditioning (HVAC); instrumentation; control; vault configuration; control and maintenance building configurations; supporting system designs; infrastructure interfaces, closure system, etc. In addition, FDNW shall also perform special design support media (letter reports, studies), including but not limited to process hazards; fire hazards; shielding; reliability, availability, and maintainability; vault and plant total operating efficiency; life-cycle cost; ${ }^{1}$ interaction; retrievability; ${ }^{2}$ operability/maintainability assessments; ant establishment of a project O\&M concept; etc. Details of the deliverables are outlined in sections 3 and 4 of this SOW.

The CD work shall be documented and summarized in a CDR. All design media prepared under this contract shall become the property of the DOE. FDNW shall use the following principal objectives to develop the CD for the Project.

- Meet all technical requirements imposed by the baseline documents (SOW and DRD).

- Provide the minimum life-cycle cost consistent with operational, environmental, security, and safety requirements.

- Meet safety, environmental, security, energy, and quality assurance (QA) requirements imposed by the baseline documents.

- Meet all applicable federal, state, and local requirements.

- Develop the Preliminary Safety Evaluation (PSE).

- Integrate the CD and the PSE.

${ }^{1}$ The evaluation is of design concepts (as outlined in the AGA) and cost of operations, including retrieval and closure, over the operating life of the vaults.

${ }^{2}$ This design should not irreversibly preclude 50 year retrievability of the waste packages. 


\subsection{DESIGN RESPONSIBILITY}

FDNW shall have sole and final design responsibility for new installations, systems, structures, and components, which are provided to support the overall ILAW disposal facility design.

\subsection{DESIGN REPORT REQUIREMENTS}

Conceptual design encompasses those efforts, that develop a project's technical scope, ensure project feasibility and performance levels, develop cost estimates, provide a complete description of the project, develop design parameters for all engineering disciplines and facility functional descriptions, provide parallel development of a PSE, and ensure full technical integration between the CDR and the PSE. Appendix A contains the requirements for development of the PSE.

The $\mathrm{CD}$ effort shall produce new design media utilizing existing designs and associated engineering and project documents to the fullest extent practical. FDNW shall be responsible to retrieve and review (from Project Holding) those files and documents that provide a technical basis for the conceptual design and future design efforts (including site drawings, water supply documentation, etc.)

Table 2-1 is a summary list of deliverables needed to help support the "validation" process, and denotes who has the lead responsibility. Those items in which FDNW has the lead responsibility are to be deliverables in the CDR. 
Table 2-1. Summary List of Deliverables to Support Validation Process.

\begin{tabular}{|l|c|}
\hline \multicolumn{1}{|c|}{ Deliverable } & Lead responsibility \\
\hline Site Development Plan & FDNW \\
\hline Work Breakdown Structure & FDNW/TR \\
\hline BA/BO Schedule & FDNW \\
\hline $\begin{array}{l}\text { Cost estimate: } \\
\text { Total estimated cost } \\
\text { Other project cost }\end{array}$ & FDNW \\
\hline Troject Schedule & FDNW \\
\hline Outline Specification & FDNW \\
\hline Energy Conservation Report & FDNW \\
\hline Preliminary Safety Evaluation & FDNW \\
\hline Economic Analysis and Life Cycle Cost Analysis & FDNW \\
\hline Physically Handicapped Assessment & TR \\
\hline Plant Forces Work Review & TR \\
\hline Sketches or Drawings & FDNW \\
\hline Major Equipment List & FDNW \\
\hline Draft Integrated Logistics support Plan (ILSP) & TR \\
\hline Level 1 Baseline Schedule & TR \\
\hline Additional Supporting Documentation (e.g. project plan) & TR \\
\hline
\end{tabular}

FDNW $=$ Fluor Daniel Northwest

$\mathrm{TR}=$ Technical Representative.

\subsection{SCHEDULE}

The CD efforts for the ILAW Disposal Facility Project are scheduled to begin by February 1998, with CDR completion (for Project Hanford Management Contractor [PHMC] and RL review) by December 1998. The FDNW CD deliverable dates are presented in Table 2-2. 
Table 2-2. Conceptual Design Deliverable Schedule.

\begin{tabular}{|l|c|}
\hline \multicolumn{1}{|c|}{ Deliverable } & Date \\
\hline Submit work plan for Site Development Plan & $3 / 2 / 98$ \\
\hline Submit work plan for conceptual design & $3 / 20 / 98$ \\
\hline Submit work plan for PSE & $3 / 27 / 98$ \\
\hline $\begin{array}{l}\text { 30\% Review--Submit Site Development Plan, Flow Sheet(s) and } \\
\text { single design concept for further development including sketches } \\
\text { in sufficient detail to convey all pertinent concepts, see Section } \\
\text { 3.4.6.4 }\end{array}$ & $6 / 1 / 98$ \\
\hline $\begin{array}{l}\text { Submit 90\% media including a Design Report, Cost Estimate, } \\
\text { Drawing Package, Specifications, and all other contractual } \\
\text { specified documents and deliverables, see Section 3.4.6.4 }\end{array}$ & $8 / 14 / 98$ \\
\hline Issue final PSE & \\
\hline Issue final CDR including those items in Table 2-1, including PSE & 8/28/98 \\
\hline $\begin{array}{l}\text { Note: An informal/over-the-shoulder review will be made at the } \\
60 \% \text { stage. }\end{array}$ & TBD \\
\hline
\end{tabular}

$\mathrm{CDR}=$ Conceptual Design Report

Note: Specifics of $30 \%, 60 \%$, and $90 \%$ reviews are covered in Section 3.4.6.4.

\subsection{BASIS OF DESIGN}

The CD shall meet the requirements specified in the DRD which will be provided by the TR at the start of the $\mathrm{CD}$ effort. This document may be revised as required by the TR.

\subsection{PRELIMINARY INFORMATION}

The following provides a preliminary list of information items that will be available at the beginning of the $\mathrm{CD}$ effort.

Criteria documents

- HNF-2211, W-520 Design Requirements Document

- Project summary work breakdown structure

- HNF-PRO-562, Conceptual Design Report Procedure

Information documents

- HNF-SD-TWR-AGA-004, ILAW Alternative Generations Analysis 
HNF-2153, Rev. 0

- WHC-SD-WM-SE-021, Tank Waste Remediation System Complex Site Evaluation Report

- HNF-2110 Phase 1 ILAW Operational Source Term

- HNF-MP-599, Fluor Daniel Hanford Quality Assurance Program Description (QAPD)

- HNF-PRO-261, Quality Assurance Program Plans

- HNF-SD-WM-SEMP-002 TWRS Systems Engineering Management Plan (SEMP)

- HNF-1900, TWRS Configuration Management Plan

The applicable version of the documents shall be established by the TR. Any deviation from criteria documents will require appropriate $\mathrm{TR}$ and/or $\mathrm{RL}$ approvals. 
HNF-2153, Rev. 0

\subsection{PROJECT MANAGEMENT}

This section describes the customer's project management requirements to FDNW for the project CD effort.

\subsection{MANAGEMENT APPROACH}

The TRs have the responsibility and authority for technical direction of FDNW's activities within the scope of this SOW. Any changes to the requirements of this SOW, or direction that impacts any of the contract cost/schedule provisions or its terms or conditions, must come only from the TR's contract administration. In preparation of the conceptual design; FDNW shall recognize that RL will be the owner of the ILAW disposal facility. Oversight of the Project activities will be provided by the director of the RL Waste Disposal Division (WDD). Overall project management will be provided by the TRs. Administration of the FDNW contract will be provided by the designated TR's contract specialist assigned by the TR's Procurement organization.

\subsection{CONCEPTUAL DESIGN WORK PLANS}

The CD work plans shall identify objectives, approach, activities, deliverables, overall schedule, and resources required to accomplish each specific task. The work plan information should be presented in a manner consistent with the contractor work breakdown structure (CWBS). The estimated number and type of engineering sketches, specifications, calculations, reports, etc., for each work element shall be provided. The work plans shall include, but not be limited to, the following:

- Statement of Methodology - Identify the objective, technical approach, and organizational structure for completion of this SOW.

- Organization - Identify the key technical members and the management assigned to this effort.

- Task descriptions - Describe the technical scope of work to be performed for each task including (e.g. FHA, PSE), but not limited to, those listed in Sections 3.0 and 4.0. To the extent possible, describe the level of details planned for each task.

- Task Activities - For each task, identify the activities to be performed, and list specific documents and types of design sketches/diagrams/schedules to be produced and include a bar chart schedule with total resources required, including estimated staff hours.

- Master Schedule - Include a master contract schedule per Section 3.4.2.

The work plans shall meet all CD and PSE deliverables and work scopes as defined in the SOW; including all applicable items defined in Sections 3.0, 4.0, and Appendix A of this SOW. The work plan shall be submitted for TR review and approval prior to initiation of $\mathrm{CD}$ activities. FDNW shall maintain the approved CD work plan, review and report against the plan on a 
HNF-2153, Rev. 0

monthly basis, and inform the TR of any changes or deviations that will result in changes to the CD work scope and schedule.

\subsection{BUSINESS MANAGEMENT}

\subsubsection{Project Planning and Budgeting}

FDNW shall provide support (mainly a schedule, monthly report, and cost roll-up) and develop information, as requested by the TRs, to support preparation of documentation as required for budget submittals and other planning activities. The monthly report shall include a Budgeted Cost Work Performed (BCWP), Budgeted Cost Work Scheduled (BCWS), and Actual Cost Work Performed (ACWP) project status format with variances at the project level.

\subsubsection{Work Planning and Scheduling}

The project summary work breakdown structure (PSWBS), shown in Table 3-1, shall be used by FDNW as the basis for developing its own CWBS. FDNW's work definitions, estimate hours, schedules, and cost estimates shall be prepared in accordance with the CWBS.

The master schedule shall show review periods, monthly reports, significant interfaces with the customer, and all deliverables identified in section 4.2 . 
Table 3-1. Project Summary Work Breakdown Structure.

\begin{tabular}{|c|c|}
\hline $\begin{array}{c}\text { Work breakdown structure } \\
\text { number }\end{array}$ & Title \\
\hline 1 & TWRS Program \\
\hline 1.3 & Waste Retrieval \\
\hline 1.3 .4 & Immobilized Waste \\
\hline 1.3 .4 .1 & ILAW Disposal \\
\hline 1.3 .4 .1 .1 & Project Administration \\
\hline 1.3 .4 .1 .2 & Systems Definition \\
\hline 1.3 .4 .1 .3 & Performance Assessment \\
\hline 1.3 .4 .1 .4 & ILAW Projects \\
\hline 1.3.4.1.4.1 & Project W-465 \\
\hline 1.3 .4 .1 .4 .2 & Project W-520 \\
\hline 1.3 .4 .1 .4 .2 .1 & Project Manager \\
\hline 1.3 .4 .1 .4 .2 .2 & Conceptual Design \\
\hline 1.3 .4 .1 .4 .2 .2 .1 & Vault \\
\hline 1.3.4.1.4.2.2.2 & Liner/Leachate Collection System \\
\hline 1.3 .4 .1 .4 .2 .2 .3 & Equipment \\
\hline 1.3.4.1.4.2.2.4 & Transportation \\
\hline 1.3.4.1.4.2.2.5 & Support Structures \\
\hline 1.3.4.1.4.2.2.6 & Infrastructure \\
\hline 1.3 .4 .1 .4 .2 .2 .7 & Closure System \\
\hline 1.3 .4 .1 .4 .2 .3 & ACDR \\
\hline 1.3 .4 .1 .4 .2 .4 & Preliminary Detailed Design (Title I) \\
\hline $1.3 .4 \cdot 1.4 .2 .5$ & Definitive Design (Title II) \\
\hline 1.3 .4 .1 .4 .2 .6 & Construction \\
\hline $1.3 .4 \cdot 1.4 .2 .7$ & Startup \\
\hline 1.3 .4 .1 .4 .2 .8 & Permitting \\
\hline 1.3 .4 .1 .4 .2 .9 & Safety \\
\hline 1.3 .4 .1 .5 & Operations \\
\hline 1.3 .4 .1 .6 & Future Projects \\
\hline 1.3 .4 .1 .7 & Facility D\&D/Closure \\
\hline
\end{tabular}

FDNW shall prepare a contract master schedule and schedules for the $\mathrm{CD}$, and the PSE. These schedules shall be developed in sufficient detail to plan and control the required work tasks. The schedules shall be included in the work plans and contain the following:

- A time-phased, resource-loaded, logic-based schedule for all CD tasks

- Indication of key deliverables, including those required by this SOW

- Be supported by lower-level discipline schedules as necessary 
- Be updated monthly to reflect agreed-upon changes

- Be in a P3 format.

\subsubsection{Work Breakdown Structure}

FDNW shall develop a CWBS for review and approval by the TRs. The CWBS shall identify all work to be accomplished. All planning and performance measurement shall be based on the approved CWBS and include the following requirements.

- Be compatible with and support the PSWBS.

- Provide for a logical CWBS and PSWBS roll up of all budget, earned-value, and cost data.

- Provide a CWBS dictionary description for each element.

\subsubsection{Work Authorization and Funds Control}

All work authorization and funds control and changes to new work scope resulting from technical direction issued by the TRs shall be in accordance with the NHC/FDNW contract.

\subsubsection{Performance Measurement and Reporting}

A time-phased performance measurement baseline (PMB) (staff hours and dollars) for completing the CD shall be prepared by FDNW and be included in the CD work plans. The PMB shall:

- Be consistent with directed work scope, work plans, CWBS, etc.

- Be structured by CWBS level

- Be maintained through FDNW's change control process and updated as required

- Be consistent with and roll up to the CWBS reporting level baseline (one baseline) at the lowest level

- Be documented to the lowest level of the CWBS, including the earned value methodology to be used.

- Be statused monthly and transmitted formally to the TR in accordance with section 3.4.6.1.

FDNW shall submit and provide cost and schedule input in accordance with the TRs' requirements, that provides integrated CWBS cost/schedule data for measuring performance. Earned value progress and any changes in the latest revised estimate shall be included in the cost 
performance report with variance explanations. All of FDNW's detailed budget information (staff hours and dollars) below the CWBS level shall be available for review by the TRs as required.

Variance analysis shall be on the current month and cumulative-to-date, and shall include cause, effect, and corrective action. Variance analysis shall be prepared at the CWBS level with explanation lower as required to adequately address problems (offsetting variances). Variance analysis thresholds (current month and cumulative-to-date) shall be given by the TR.

\subsubsection{Management Reports, Meetings, and Reviews}

3.4.6.1 Management Reports. FDNW shall provide the TRs copies of their internal weekly summary reports. Additionally, FDNW shall provide monthly activity status reports that shall be submitted by the 5th of each month with the cost performance reports and shall include, but not be limited to, the following information:

- Project manager's narrative highlights and status assessment for each CWBS element including activities planned for the next month

- Issues/concerns (cost, schedule, technical), recommended resolution, and progress toward resolution

- New or outstanding agreements and/or commitments for problem or technical issue resolution.

3.4.6.2 Monthly Review Meetings. Monthly meetings shall be held at the FDNW offices, before issuance of the monthly report or immediately thereafter, to review work progress. During these meetings, FDNW shall present project technical progress, cost, and schedule status for each task. During the presentation, FDNW shall identify existing or anticipated problem areas for each task (including impacts), and report on progress toward problem resolution. FDNW shall prepare and distribute the meeting minutes within 10 working days after the meeting. Minutes shall emphasize agreements, commitments, and planned actions. The minutes text shall receive the TR's management concurrence before minutes issuance.

3.4.6.3 Kick-Off Meeting. A design kickoff meeting and PSE kickoff meeting will be held at FDNW's offices or another location specified by the TR after issuance of a Notice To Proceed. The meetings will provide a "facilitated partnering session", set up by the TRs, for RL project management, and the principals of FDNW before preparation of the work plans. These meetings will focus on a discussion of the CD work scope and the goal, role, and responsibility of each project participant. Pertinent documents also will be reviewed and discussed. FDNW will explain how they intend to take advantage of previous experience and personnel.

3.4.6.4 Design Review Meetings. Design review meetings shall be convened at the 30 percent and 90 percent completion points to ensure that the design objectives are being achieved. An inprocess 60 percent design review will be held as described below. Design reviews shall be identified in the work plans. Intermediate PSE reviews are specified in Appendix A. The following definitions for design reviews will be considered the minimum requirements with the final details negotiated with FDNW. 
HNF-2153, Rev. 0

A 30 percent design completion is the point when a flowsheet or material handling diagram has sufficient detail to be the basis for a single design approach from that point forward, (e.g. various concepts have been developed and evaluated such that a single concept is selected for development and final design). Deliverables include, at a minimum, the following:

- Site Development Plan

- CDR outline

- Transport system concept - (W-465 concept)

- Flowsheet(s) or material flow diagrams (MFD), including throughput; product description and characteristics; and interfaces with other projects, existing and future facilities Flowsheets shall be prepared to cover two scenarios,

- Activities for the remainder of Privatization Phase I

- Activities at the peak production rate of Privatization Phase II

- Alternatives considered and the basis for a single design concept for further development including sketches in sufficient detail to convey the concept

- Any uncertainties that require resolution and the stage at which resolution must occur

- Outline and approach to all other $\mathrm{CD}$ issues.

For the 30 percent design review, FDNW shall plan a one to two day meeting at their offices with the principals of FDNW and the TR to reach a consensus of the 30 percent approach above. Comments about the content will be informally (via sketch markups, and/or note, letter type responses) issued, and only those things found to be of a significant technical nature will be formally documented, action traced and resolved in a timely fashion, to not jeopardize design completion.

A 60 percent design completion will be the point where detailed sketch drafts and draft outline specifications are available for initial review such that sufficient detail is provided so that the design development can be well understood. The design and construction approach should be understood and agreed to at this point (build to print, performance specification, design-build, etc.). See Schedule Section 2.4.

A 90 percent design completion is the point where FDNW has completed all the design media for that stage of design and is ready to submit the entire design package to the design agent for review. Further work on any portion of the package is limited to incorporating design review comments from the design authorities' review. The principle deliverables at 90 percent include:

- CDR Report and executive summary

- Operations/Construction access assessment (Site Development Plan)

- Flowsheet(s)/MFD(s) 
- Design Analysis (structural, shielding, etc.)

- WBS/CWBS

- Cost estimate

- Total estimated cost

- Other project cost

- $\mathrm{BA} / \mathrm{BO}$ schedule

- Project Schedule

- Definitive Design schedule

- Construction schedule

- Outline specifications

- A major equipment list

- Energy Conservation Report

- Economic Analysis and Life Cycle Cost Analysis

- Physically Handicapped Assessment

- Sketches or Drawings

- Preliminary Safety Evaluation

- Draft Plant Forces Work Review

- Additional Supporting Documentation (e.g. calculation list, safety documentation, fire hazards analysis, closure system design, and items in section 4.2 not covered above)

For the 90 percent formal review, FDNW and the TR shall pre-agree on the location for this meeting depending upon timing, staff, etc., and shall be conducted in accordance with requirements of the TR's design procedures and guidelines. This review will be in accordance with the design review plan.

At the completion of the Conceptual Design and before transmittal of the FDNW design package for review, a summary level "walk-through" of the design shall be presented by FDNW's lead engineer, after which final review comments will be prepared and submitted by the TRs, to FDNW.

All of these reviews shall be indicated on the contractor master schedule. 
3.4.6.5 Coordination Meetings. Coordination meetings, including telephone conferences, will be held, as required, between the TRs and FDNW to discuss various project issues as they arise. Meeting minutes will be prepared by FDNW and issued to the meeting participants within three working days of the meeting for review and comments. Meeting minutes shall be issued within ten working days of the meeting. The minutes' text shall receive the TRs' concurrence before minutes issuance.

3.4.6.6 Communications. Any oral communications (including telephone conferences and meeting minutes), or informal written communications (e.g., cc:mail, facsimiles), having an impact on the approved work scope shall be brought to the attention of the TRs by FDNW as soon as possible, but absolutely before any action is taken by FDNW. If appropriate, these communications will be formalized by official written communication from the contract administrator.

\subsection{DOCUMENT REQUIREMENTS}

Record documents and contract documents will be generated during the course of the design. Record documents are those end-item documents required by this SOW. Contract documents are those documents that implement the contract and include the contract and all requirements, references, records, and other related documents.

\subsubsection{General Data}

All engineering deliverables shall be prepared using SI units. Sketches shall be prepared using a computer-aided design and drafting (CADD) process. Any exceptions shall be identified and submitted to the TRs for approval. Software used for CADD tools must be available to the TR. If A-E proprietary software is used, the TR shall have free access to it after the CD phase to the extent legally possible: All commercial software and user rights purchased by the project shall be transferred to the TRs on or before the project completion.

Full-size sketches shall be 71 by $102 \mathrm{~cm}$ ( 28 by $40 \mathrm{in}$.). Reduced sketches can be 36 by $50 \mathrm{~cm}$ ( 14 by $20 \mathrm{in}$.) if mutually agreed upon by the TR and FDNW. Sketches included in topical reports can be 28 by $43 \mathrm{~cm}$ (11 by $17 \mathrm{in}$.) or 21 by $28 \mathrm{~cm}$ ( 8.5 by $11 \mathrm{in}$.). Sketch sizes other than those listed may be accepted on a mutually agreed upon basis. Reproducibles for sketches shall be furnished by FDNW pending approval by the TR.

\subsubsection{Document Control}

Preparation, identification, approval, transmittal, and final disposition of record documents shall conform to guidance given by the TRs. If the is no guidance, use of FDNW's established procedures or special instructions is required. Use of contract documents shall be controlled in accordance with FDNW's established procedures or special instructions. 
HNF-2153, Rev. 0

\subsubsection{Document Identification and Format}

The CDR shall be developed in accordance with HNF-PRO-562, Conceptual Design Report procedure. The PSE shall be developed in accordance with HNF-PRO-703, Safety Analysis Process-New Project.

3.5.3.1 Numbering System. FDNW is required to use the Hanford Site Controlled Document numbering system for all documents, technical reports, sketches and specifications, etc. The numbers will be provided to FDNW by the TRs.

3.5.3.2 Format. Each deliverable record document shall show the following:

- Project and contract identification

- ILAW Disposal Facility

- Project number: W-520

- Contract number: To be determined

- Originating firm's name

- End-item document title

- Work breakdown structure (WBS) number

- Document level of approval

- Document identification number (on each page)

- Document descriptive title

- Revision or addendum number or letter (on each page with revised portion of the page indicated)

- Issue or revision date (released documents only)

- Total number of pages and number of each page

- Table of contents and attachments (as needed)

- Approval signature and title of responsible person in originating firm (for released documents only).

3.5.3.3 Engineering Sketches. Sketch numbers will be provided by FDNW in accordance with Hanford nomenclature. Each sketch shall include a list of interfacing sketches. 
HNF-2153, Rev. 0

\subsubsection{Document Approval}

All engineering sketches and technical documents submitted to the TRs for review shall first be thoroughly reviewed by appropriate members of FDNW's technical staff. FDNW shall have written procedures in place that delineate the requirements for reviewing, checking, technical editing, and approval of documents before issuance.

Acceptance by the TRs is the act of reviewing an activity or document, and acknowledging that it may be used for the purpose intended at that time. Acceptance by the TRs does not ensure that future changes will not be required, and does not convey or imply approval, or assumption of responsibility for the activity or document. The originator remains fully responsible for all aspects of the activity or document, for fulfilling all specifications, and for any other obligation or liability otherwise arising under a specification, agreement, or contract.

\subsubsection{Document Transmittal}

Unless otherwise agreed upon, transmittal of record documents shall include one reproducible, 20 copies, and one electronic copy. For documents larger than 21 by $28 \mathrm{~cm}$ ( 8.5 by 11 in.), full-size, photo-quality reproducibles shall be included. Transmittal of record documents produced electronically shall include indices that identify directory and data set file names. Transmittals shall be prepared consistent with section 3.5.3.2 and in accordance with DOE Order 1324.5B, Records Management Program (DOE 1995) and the FDNW Project document transmittal procedure.

\subsubsection{Record Files}

Record files, those documents that describe or support the project technical baseline (e.g. requirements, calculations, sketches), with current and previous revisions shall be maintained for record documents in accordance with FDNW's approved configuration control program. FDNW shall provide a list of record documents to the TR for concurrence. At the conclusion of $\mathrm{CD}$, the TR will advise FDNW of the file's disposition. FDNW shall keep duplicate copies of data to meet code or legal requirements.

\subsection{QUALITY ASSURANCE}

Fluor Daniel Northwest (FDNW) shall submit for review and implement a W-520 Project Quality Assurance Program Plan (QAPP). The project-specific QAPP shall be developed in accordance with requirements for project QAPPs listed in Project Hanford Policies and Procedures HNF-PRO-261 Quality Assurance Program Plans. The project QAPP shall be based on the quality assurance requirements appearing in the Fluor Daniel Hanford Quality Assurance Program Description (QAPD), HNF-MP-599 Part 2, sections 1 - 9. The project QAPP shall be prepared during conceptual design phase of the project. At a minimum, the project QAPP shall be approved by the individuals identified in Appendix F of HNF-PRO-261. Those individuals include the FDNW President, the FDNW QA manager, the FDNW manager of the W-520 project, the FDH QA manager, and the FDH Project Director. 
HNF-2153, Rev. 0

\subsubsection{Accessibility for Assessment Purposes}

FDNW shall allow access to all documents, files, and workstations for purposes of assessment or surveillance of activities by the Project Hanford Management Contractor (PHMC) or their designated agents. FDNW shall provide support, as requested, for assessments or . surveillances conducted by the PHMC.

\subsubsection{Sub-tier Contractor QA Programs}

Sub-tier contractors to FDNW shall have Quality Assurance programs applicable to their portion of the FDNW work scope. Sub-tier contractors' QA programs must implement the relevant requirements of HNF-MP-599, Part 2, Sections 1-9, and FDNW shall approve any such sub-tier contractor programs.

\subsection{SYSTEMS ENGINEERING MANAGEMENT}

FDNW shall plan and manage, at a minimum, the following systems engineering elements as a part of the CDR and PSE: analysis of DRD requirements and traceability into the CDR; identification of alternatives considered for each major subsystem and the basis for alternative selection; identification of enabling assumptions that could influence the scope, cost or schedule; and identification of risks associated with the design and construction that could influence scope, cost or schedule. These elements shall be applied to deliverables provided to FDNW including but not limited to: Project Design Concept; Outline Design Specifications; Logistics Plans (MFDs); Energy Conservation Report, Fire Hazards Analysis, Project Interface Control Drawings; and if requested, Preliminary Design Analysis Calculations (See Table 2. TWRS SEMP).

\subsection{SAFETY}

See Appendix A. 
HNF-2153, Rev. 0

\subsection{DESCRIPTION OF REQUIRED SERVICES}

FDNW is the fully responsible design agent for translating Project requirements into a costeffective $C D$ that satisfies all programmatic and technical requirements. The tasks described in this section and Table 4.1, Deliverables for the W-520 CDR, are those that the TRs has specifically identified as necessary for CD development but does not include "all technical tasks" that are necessary to produce an acceptable CD. FDNW is required to supplement this task list by adding other necessary work items or upgrading the TR's work scope definition of identified tasks, as necessary to satisfy its assessment of the effort needed to produce an acceptable CD satisfying all technical and quality requirements.

\subsection{DESIGN OBJECTIVES}

The overall $\mathrm{CD}$ objective is to develop an initial project baseline, consistent with program goals, that defines the project cost, schedule, and technical performance.

The principal objectives of the $\mathrm{CD}$ are as follows:

- Prepare an integrated Site Development Plan that accommodates delivery of the peak production rate number of disposal packages (currently estimated at approximately 27 packages per day) while permitting simultaneous access to equipment and services required for the construction of subsequent disposal modules. This plan shall be provided as a $30 \%$ design deliverable.

- Develop the ILAW disposal facilities and infrastructure to a level of detail sufficient to develop budget validation documents, in accordance the schedule in Table 2-2.

- Establish the initial project baseline including cost and schedule project baseline, further define the technical scope, and document them in a CDR.

- Develop a conceptual design and estimate for the entire ILAW Disposal Facility closure system and include as an appendix to the CDR. This closure system design will dictate the design of the system on the W-465 ILAW vaults.

- Develop a conceptual design for the entire ILAW Disposal Facility infrastructure.

- Develop a cost and construction schedule for the construction of a standard sized disposal module with features that can be removed as necessary in subsequent modules. Potentially removable features are described in the AGA (Burbank 1997). Option $2 \mathrm{~A}$ of the AGA describes the basis of standard module.

\subsection{WORK ITEMS}

FDNW is required to perform, at a minimum, the following Project activities:

1. Review preliminary information provided for the Project (Section 2.6). 
2. Identify key staff assigned to the project and submit evidence of their qualifications to the TR. The TR shall have approval over the assignment of key staff to the project.

3. Prepare three Engineering Work Plans in accordance with Section 3.3, that describe the means by which FDNW will prepare the site development plan, the $C D$, and the PSE, including specific technical tạsks and services defined in this SOW. Fully define the level of technical detail that will be provided in the design media, such as plant arrangements, electrical one-line diagrams, flow diagrams, piping and instrumentation diagrams, and other relevant depictions. These design media shall adequately present the ILAW disposal facility design concept by outlining new facility features, vault arrangements, etc.

4. Prepare a site development plan that outlines the construction sequence and the development of the 90 acre site on an as needed basis to support both construction and operations during Phase I and Phase II of the privatization contract. The site development plan must detail how the site will accommodate operations at the peak package delivery rate and still allow access for construction traffic and maintenance personnel. In addition to personnel and traffic logistics, the plan and sequence of the development of all operations and construction utilities must be outlined.

Provide material flow diagrams in the site development plan for two scenarios: 1) Privatization Phase I peak flow, and 2) Privatization Phase II peak flow. This work element requires a conceptual engineering effort to develop a physical process flow (time/motion) description for ILAW onsite transport and disposal (i.e., operational steps, sequences, durations, etc. associated with the movement of ILAW containers from production facilities through disposal). Also, determine the number of on-site shipping containers and transporters required to support the receipt rate. The bases for the above statements are specified in the DRD (Burbank 1998).

The container physical process flow shall cover the period beginning with receipt at the production facility, through transport to and unloading at the disposal facility. At the time of acceptance, the ILAW packages are themselves contained within an onsite shipping container that is ready to be loaded on a transportation vehicle. The shipping packages have been certified by the producer to satisfy all onsite transport requirements (e.g., leak-tight, free of surface contamination, etc.).

The site development plan shall also identify ILAW Disposal Facility interfaces between the new facility systems, and facilities outside the new disposal complex. Particular emphasis shall be directed towards interface requirements related to the ILAW production facilities and Hanford Site infrastructure. Define the following, at a minimum:

- Physical interface points and requirements, new facility requirements, including transportation systems (e.g., size requirements; handling features, such as lifting pintle design, flow capacity, pressure, materials of construction, etc.) and infrastructure. 
- Functional interfaces such as effluents, solid waste, support facilities, etc. not covered by the existing facility operation.

- Technical requirements of interfacing facilities/systems for new facilities.

Where interface information is available, and required for design, it shall be so noted in the site development plan.

5. Prepare a compliance matrix to show the CDR meets the requirements of the $\mathrm{DRD}$ and SOW.

6. Prepare a project cost estimate at the WBS level, based on material takeoffs and vendor quotations, and recent facility (i.e., Project W-465) costs. The estimate shall use rates included in approved Hanford Site construction estimate factors. The $\mathrm{BA} / \mathrm{BO}$ schedules, estimator's work sheets, vendor quotations, and basis of the estimate for each item shall be included. FDNW shall develop a total project cost (TPC), with contingency, with OPC input from the TR. The Project cost estimate data shall be electronically stored, and shall be capable of providing information sorts by DOE code, WBS, work package, facility, system, and Construction Specification Institute format.

7. Develop a definitive design and construction schedule for the first two ILAW Disposal Modules and the entire disposal site infrastructure including all its major components. Prepare, as a minimum, a preliminary list of items for the following:

- Long lead equipment

- Long lead time for fabrication

- Major equipment list detailing critical design features and operating limits

- Systems, structures, and components important to safety.

8. Perform all engineering tasks necessary to develop a CD of the ILAW Disposal Facility Project that depicts new facility features, transportation system, equipment arrangements, infrastructure, and closure system. Conceptual Design sketches (with related design analyses), and outline specifications, shall be prepared and issued to document new design features and related design analyses, and to establish the engineering baseline for support systems and facilities. As a minimum, the following types of analysis, engineering sketches, and outline specifications shall be developed, as required, to depict new installation of structures, systems, and components:

- Site plans

- Site layout

- Flow Sheets

- Architecture/Civil/Structural

- General arrangement

- Space allocations

- Electrical

- Mechanical 
- Communication system

- Fire detection/protection

- HVAC

- Transportation systems

- Support systems.

- Infrastructure interfaces

- Life Safety

- New infrastructure features

9. Develop a CDR that describes the ILAW disposal facility and process sequences; identifies process control philosophies and potential failure recovery features; establishes an O\&M concept; identifies and address the risks and uncertainties associated with the specified design concept(s); documents alternatives evaluated and significant technical findings and/or describes significant Value Engineering studies that provide the basis of choice for those items specified in Section 2.1; and provides recommendations. Additionally, the CDR shall indicate that a human factors analysis will be completed after the Ram analysis; and that the equipment testing and test plan and development of technical performance measures will be completed in definitive design.

10. Prepare Energy Conservation Report, Economic Analysis and Life Cycle Cost Analysis for AGA options, QAPP, Fire Hazards Analysis, and a list of conceptual design calculations completed.

11. Prepare PSE in accordance with Appendix A.

12. Prepare a conceptual design and cost estimate (TEC) escillated to 2030 for the entire Disposal Facility final closure system. This design is to be included as an appendix to the W-520 CDR and shall contain a narritive, sketches and estimate.

13. As part of design development for process systems, support systems, and facilities, FDNW may be directed to perform additional (not routine design) special studies/tasks, by the TR. Only after such formal direction is requested, then FDNW shall proceed with the following as guidance: Such studies shall be documented in topical reports that contain technical findings, tradeoffs, developments, analysis performed, recommendations, etc. as appropriate. A standard format shall be developed by FDNW with concurrence from the TR for use in preparing study reports. A detailed outline, including alternatives to be evaluated, work statements, decision hold points, and cost and schedule of each study, in the standard format, shall be submitted for TR approval. Once approved for execution, each task shall be monitored under a traceable budget account.

Alternatives selected for evaluation in a study shall not be limited to the requirements of the baseline documents. Selected alternatives shall be documented and maintained, and shall become part of the final documentation or report file. Proposed changes to the baseline documents that are necessary to implement the approved study recommendation shall be submitted for TR approval before the changes are 
implemented. These studies, in addition to studies performed during the normal course of FDNW's work, shall be reviewed in accordance with the design review procedure. The potential cost savings associated with each study alternative shall be quantified by performing a rough order-of-magnitude (ROM) cost estimate in conjunction with study preparation. Each ROM cost estimate shall be prepared at the direct cost level.

Table 4-1. Deliverables for W-520 CDR

\begin{tabular}{|l|l|l|}
\hline Task/Requirement/Deliverable & RESP & Due \\
\hline Three Work Plans (PSE, CDR, Site Development) including: & FDNW & $\begin{array}{l}\text { Prior to initiation of } \\
\text { work }\end{array}$ \\
$\begin{array}{l}\text { Statement of Methodology - Identify the objective, technical } \\
\text { approach, and organizational structure for completion of this } \\
\text { SOW. }\end{array}$ & & \\
$\begin{array}{l}\text { Organization - Identify the key technical members and the } \\
\text { management assigned to this effort. }\end{array}$ & & \\
$\begin{array}{l}\text { Task descriptions - Describe the technical scope of work to be } \\
\text { performed for each task (e.g. FHA, PSE) }\end{array}$ & & \\
$\begin{array}{l}\text { Task Activities - For each task, identify the activities to be } \\
\text { performed, and list specific documents and types of design } \\
\text { sketches, diagrams, and schedules to be produced and include } \\
\text { a bar chart schedule with total resources required, including } \\
\text { estimated staff hours. }\end{array}$ & & \\
$\begin{array}{l}\text { Performance measurement baseline (PMB) - staff hours and } \\
\text { dollars consistent with directed work scope, work plans, and } \\
\text { structured by CWBS level and maintained through FDNW's } \\
\text { change control process and updated as required . } \\
\text { Estimated number, and type of, engineering sketches, } \\
\text { specifications, calculations, reports, for each work element } \\
\text { shall be provided. }\end{array}$ & & \\
$\begin{array}{l}\text { Master Schedule - Show review periods, monthly reports, } \\
\text { significant interfaces with the customer, and all deliverables. } \\
\text { Work plan submitted for TR review and approval prior to } \\
\text { initiation of CD activities. }\end{array}$ & & \\
\hline $\begin{array}{l}\text { Plan a one to two day meeting for the 30 percent design } \\
\text { review with the principals of FDNW and the TR to reach a } \\
\text { consensus of the 30 percent approach. }\end{array}$ & FDNW & Prior to 30\% CDR \\
completion \\
\hline
\end{tabular}


HNF-2153, Rev. 0

\begin{tabular}{|c|c|c|}
\hline Task/Requirement/Deliverable & RESP & Due \\
\hline \multirow{3}{*}{$\begin{array}{l}\text { Prepare Flowsheet(s) or material flow diagrams (MFD) to } \\
\text { cover two scenarios: } \\
\text { Activities for the remainder of Privatization Phase I } \\
\text { Activities at the peak production rate of Privatization } \\
\text { Phase II }\end{array}$} & FDNW & $30 \% \mathrm{CDR}$ \\
\hline & & \\
\hline & & \\
\hline \multirow{3}{*}{$\begin{array}{l}\text { Integrated Site Development Plan - } \\
\text { Outline construction sequence and the development of the } 90 \\
\text { acre site on an as needed basis to support both construction } \\
\text { and operations during Phase I and Phase II of the privatization } \\
\text { contract. } \\
\text { Provide material flow diagrams in the site development plan } \\
\text { for two scenarios: 1) Privatization Phase I peak flow, and 2) } \\
\text { Privatization Phase II peak flow. The container physical } \\
\text { process flow shall cover the period beginning with receipt at } \\
\text { the production facility, through transport to and unloading at } \\
\text { the disposal facility. }\end{array}$} & FDNW & $30 \% \mathrm{CDR}$ \\
\hline & & \\
\hline & & \\
\hline \multicolumn{3}{|l|}{ Identify ILAW Disposal Facility interfaces } \\
\hline $\begin{array}{l}\text { - New facility systems, and facilities outside the new } \\
\text { disposal complex (e.g. the ILAW production } \\
\text { facilities and the Hanford Site infrastructure }\end{array}$ & & \\
\hline $\begin{array}{l}\text { - Functional interfaces such as effluents, solid } \\
\text { waste, support facilities, etc. not covered by the } \\
\text { existing facility operation. }\end{array}$ & & \\
\hline $\begin{array}{l}\text { Technical requirements of interfacing } \\
\text { facilities/systems for new facilities. }\end{array}$ & & \\
\hline $\begin{array}{l}\text { Present a summary level "walk-through" of the design by } \\
\text { FDNW's lead engineer at the completion of the Conceptual } \\
\text { Design and before transmittal of the FDNW design package } \\
\text { for review }\end{array}$ & FDNW & $\begin{array}{l}\text { Prior to issue of } 90 \% \\
\text { CDR }\end{array}$ \\
\hline
\end{tabular}


HNF-2153, Rev. 0

\begin{tabular}{|c|c|c|}
\hline Task/Requirement/Deliverable & RESP & Due \\
\hline $\begin{array}{l}\text { CDR Report with: } \\
\text { Executive summary } \\
\text { Identification of alternatives considered and the basis for } \\
\text { selection in CDR } \\
\text { Identification of enabling assumptions that could } \\
\text { influence the scope, cost or schedule } \\
\text { Identification of risks that could influence scope, cost or } \\
\text { schedule } \\
\text { Indicate in the CDR that a human factors analysis will be } \\
\text { completed after the Ram analysis; and that the } \\
\text { equipment testing and test plan and development of } \\
\text { technical performance measures will be completed in } \\
\text { definitive design. }\end{array}$ & FDNW & All CDR Reviews \\
\hline Work Breakdown Structure/CWBS & FDNW & $90 \% \mathrm{CDR}$ \\
\hline $\mathrm{BA} / \mathrm{BO}$ Schedule & FDNW & $90 \% \mathrm{CDR}$ \\
\hline $\begin{array}{l}\text { Cost estimate: } \\
\text { Total estimated cost } \\
\text { Other project cost }\end{array}$ & $\begin{array}{l}\text { FDNW } \\
\text { NHC } \\
\end{array}$ & $90 \% \mathrm{CDR}$ \\
\hline Project Schedule & FDNW & $90 \% \mathrm{CDR}$ \\
\hline Outline Specification & FDNW & $90 \% \mathrm{CDR}$ \\
\hline Energy Conservation Report & FDNW & $90 \% \mathrm{CDR}$ \\
\hline Preliminary Safety Evaluation & FDNW & $90 \% \mathrm{CDR}$ \\
\hline Economic Analysis and Life Cycle Cost Analysis & FDNW & $90 \% \mathrm{CDR}$ \\
\hline Physically Handicapped Assessment & $\mathrm{NHC}$ & $90 \% \mathrm{CDR}$ \\
\hline Plant Forces Work Review (DRAFT) & $\mathrm{NHC}$ & $90 \% \mathrm{CDR}$ \\
\hline Sketches or Drawings & FDNW & $90 \% \mathrm{CDR}$ \\
\hline Major Equipment List & FDNW & $90 \% \mathrm{CDR}$ \\
\hline Draft Integrated Logistics support Plan (ILSP) & NHC & $90 \% \mathrm{CDR}$ \\
\hline Level 1 Baseline Schedule & FDNW & $90 \% \mathrm{CDR}$ \\
\hline Fire Hazards Analysis & FDNW & $90 \% \mathrm{CDR}$ \\
\hline Design Analysis/Calculation List (structural, shielding, etc.) & FDNW & $90 \% \mathrm{CDR}$ \\
\hline QAPP & FDNW & $90 \% \mathrm{CDR}$ \\
\hline
\end{tabular}


HNF-2153, Rev. 0

\begin{tabular}{|c|c|c|}
\hline Task/Requirement/Deliverable & RESP & Due \\
\hline $\begin{array}{l}\text { Conceptual design for the Disposal Complex final cover } \\
\text { system. }\end{array}$ & FDNW & $90 \% \mathrm{CDR}$ \\
\hline $\begin{array}{l}\text { Compliance matrix - Analysis of DRD and SOW requirements } \\
\text { and traceability into the CDR. }\end{array}$ & FDNW & $90 \% \mathrm{CDR}$ \\
\hline $\begin{array}{l}\text { Conducted a } 90 \text { percent formal review, at a pre-agree location } \\
\text { in accordance with requirements of the TR's design } \\
\text { procedures and guidelines }\end{array}$ & FDNW & $\begin{array}{l}\text { Prior to issue of } 100 \% \\
\text { CDR }\end{array}$ \\
\hline Additional (not routine design) special studies/tasks & FDNW & As directed \\
\hline $\begin{array}{l}\text { Hold monthly meetings at the FDNW offices: } \\
\text { Before issuance of the monthly report or immediately } \\
\text { thereafter, to review work progress } \\
\text { To present project technical progress, cost, and schedule } \\
\text { status for each task. } \\
\text { To identify existing or anticipated problem areas for each task } \\
\text { (including impacts) } \\
\text { To report on progress toward problem resolution. } \\
\text { Prepare meeting minutes and distribute within } 10 \text { working } \\
\text { days after the meeting that emphasize agreements, } \\
\text { commitments, and planned actions; receive the TR's } \\
\text { management concurrence before minutes issuance. }\end{array}$ & FDNW & $\begin{array}{l}\text { Monthly as scheduled } \\
\text { be FDNW }\end{array}$ \\
\hline $\begin{array}{l}\text { Provide monthly report by the } 5 \text { th of each month: } \\
\text { Based on work plans, review and report against the plans on a } \\
\text { monthly basis, and inform the TR of any changes or deviations } \\
\text { that will result in changes to the CD work scope and schedule. } \\
\text { That includes Budgeted Cost Work Performed (BCWP), } \\
\text { Budgeted Cost Work Scheduled (BCWS), and Actual Cost } \\
\text { Work Performed (ACWP) project status format with } \\
\text { variances at the project level and contains variance on the } \\
\text { current month and cumulative-to-date and include: cause, } \\
\text { effect, and corrective action. } \\
\text { That is prepared at the CWBS level with explanation lower as } \\
\text { required to adequately address problems (offsetting } \\
\text { variances). }\end{array}$ & FDNW & Monthly \\
\hline
\end{tabular}


HNF-2153, Rev. 0

\begin{tabular}{|l|l|l|}
\hline Task/Requirement/Deliverable & RESP & Due \\
\hline $\begin{array}{l}\text { Provide the TRs copies of their internal weekly summary } \\
\text { reports. }\end{array}$ & FDNW & Weekly \\
\hline
\end{tabular}

\subsubsection{Design Media Transmittal}

All information and design media developed during the $\mathrm{CD}$ phase, including all support data necessary to understand the basis and assumptions for the design, must be forwarded to the TR for use as a basis in future design phases. 
HNF-2153, Rev. 0

\subsection{REFERENCES}

10 CFR 830.120, "Quality Assurance," Code of Federal Regulations, as amended.

62 FR 8693, 1997, Record of Decision for the Tank Waste Remediation System, Federal Register, Vol. 62, pp. 8693, February 26, 1997.

Bores, J.F., 1998, Tank Waste Remediation System Quality Assurance Program Plan, HNF-IP0842, Volume XI, Section 1.1, Rev. 0, prepared by Lockheed Martin Hanford Corporation for Fluor Daniel Hanford, Inc., Richland Washington.

Burbank, D. A., 1997, Analysis of Alternatives for Immobilized Low-Activity Wasté Disposal, HNF-SD-TWR-AGA-004, Rev. 0, SGN Eurisys Services Corporation, Richland, WA.

Burbank, D. A., 1998, Design Requirements Document for the Immobilized Low Activity Waste Disposal Project [DRAFT], HNF-2211, SGN Eurisys Services Corporation, Richland, WA.

Burbank, D. A., 1998, Phase I Immobilized Low-Activity Waste Operational Source Term, HNF2210, SGN Eurisys Services Corporation, Richland, WA.

DOE, 1991, Records Management Program, DOE Order 1324.5B, U.S. Department of Energy, Washington, D.C.

FDH, 1997, Conceptual Design Report Procedure, HNF-PRO-562

FDH, 1997, Quality Assurance Program Plans, HNF-PRO-261

FDH, 1997, Fluor Daniel Hanford Quality Assurance Program Description (QAPD), HNF-MP599

Mann, F.M., 1998, Hanford Immobilized Low-Activity Tank Waste Performance Assessment, DOE/RL-97-69, Lockheed Martin Hanford Company, Richland, Washington.

Peck, L. G., 1998, Tank Waste Remediation System Systems Engineering Management Plan, HNF-SD-SEMP-002, Rev. 1, Lockheed Martin Hanford Company, Richland, Washington.

RL, 1996b, TWRS Privatization Contract Awards, DE-RP06-96RL13308 and 13309, September 25, 1996, U.S. Department of Energy, Richland Operations Office, Richland, Washington.

Shade, J.W. 1997, TWRS Retrieval and Disposal Mission Immobilized Low-Activity Waste Disposal Plan, HNF-1517, Rev. 0, prepared by 66Numatec Hanford Corporation for Fluor Daniel Hanford, Inc., Richland, Washington

Shord, A. L., 1995, Tank Waste Remediation System Complex Site Evaluation Report, WHCSD-WM-SE-021, Rev. 0, Westinghouse Hanford Company, Richland, Washington. 


\section{HNF-2153, Rev. 0}

Taylor, W. J., 1996, letter to the President, Westinghouse Hanford Company, Richland, Washington, 96-WDD-149, (September 27), U.S. Department of Energy, Richland, Washington.

Vann, J. M., 1998, Tank Waste Remediation System Configuration Management Plan, HNF1900, Rev. 0, Lockheed Martin Hanford Company, Richland, Washington. 
HNF-2153, Rev. 0

\subsection{GLOSSARY}

\section{LIST OF TERMS}

A-E

ADP

AGA

ASME

ANSI

$\mathrm{BA} / \mathrm{BO}$

CADD

CD

CDR

CFR

CWBS

DRD

FDH

FDNW

HVAC

ILAW

MFD

QA

PHMC

PMB

PSE

PSWBS

$\mathrm{RL}$

ROM

SEMP

SOW

TBD

TEC

TR

TWRS

WBS
Architect-Engineer

Automated Data Processing

Alternative Generation and Analysis

American Society of Mechanical Engineers

American National Standards Institute

Budget authorized/budget obligation

Computer-aided design and drafting

Conceptual design

Conceptual design report

Code of Federal Regulations

Contractor work breakdown structure

Design requirements document

Fluor Daniel Hanford

Fluor Daniel Northwest

Heating, ventilating, and air conditioning

Immobilized low-activity waste

Material flow diagrams

Quality assurance

Project Hanford Management Contractor

Performance measurement baseline

Preliminary Safety Evaluation

Project summary work breakdown structure

U.S. Department of Energy, Richland Operations Office

Rough-order-of-magnitude

Systems Engineering Management Plan

Statement of work

To be determined

Total estimated cost

Technical Representative

Tank Waste Remediation System

Work breakdown structure 
HNF-2153, Rev. 0

\section{APPENDIX A}

STATEMENT OF WORK DETAILS ON PREPARATION AND DELIVERY OF THE PRELIMINARY SAFETY EVALUATION FOR PROJECT W-520

A -0 


\section{A.1 Requested Services}

This Statement of Work (SOW) describes the expectations and work scope to be performed by FDNW, under the direction of a Licensing Engineer (Technical Representative (TR)) assigned to TWRS Nuclear Safety \& Licensing, Operations and Project Safety Support (OPSS). The OPSS organization within TWRS Nuclear Safety and Licensing (NS\&L) is part of Duke Engineering \& services Hanford (DE\&SH). It serves Lockheed Martin Hanford Company (LMHC) by setting licensing strategies for major projects, programs and activities and by orchestrating implementation of the strategies. In addition, it is the responsibility of OPSS to build and maintain a centralized TWRS nuclear safety authorization basis (i.e., ensuring technical consistency across all projects; strategizing for ease of long-term management of safety authorization basis; and setting high standards for quality, integrity and clarity of safety documentation).

FDNW shall prepare a Preliminary Safety Evaluation (PSE). for the Immobilized LowActivity Waste (ILAW) Disposal Facility in compliance with the requirements as described in this SOW. The PSE shall be developed in concert with the conceptual design being developed by FDNW. FDNW shall ensure technical consistency between the PSE and all other conceptual design documentation. FDNW shall treat the PSE and its development as an integral part of the conceptual design and the deliverables prepared to ultimately support Project budget validation.

\section{A.2 Staff Integration}

The PSE work described in this SOW requires a strong interface with TWRS Nuclear Safety \& Licensing, specifically with the Operations and Project Safety Support (Licensing Engineer). In addition, the PSE development team needs to closely work with the design team to be continuously aware of the design status as well as to oversee the actual integration of the safety requirements in the design. In its Work Plan for the development of the PSE, FDNW is requested to provide the list of the personnel planned to be assigned on this task and specify their qualifications.

The TWRS NS\&L OPSS will supply the Technical Representative for the PSE development. The Licensing Engineer will serve as the daily point of contact for FDNW safety analysis personnel. TWRS NS\&L management will provide technical oversight and monitor FDNW progress on deliverables.

\section{A.3 Work Scope}

This SOW describes the required safety activities needed to support the ILAW Disposal Facility Conceptual Design phase to be performed through a PSE according to HNF-PRO-703, Safety Analysis Process-New Project. The long term Authorization Basis strategy development for this project is out of the scope of this SOW. A specific Safety Plan will be developed in parallel by TWRS NS\&L. TWRS NS\&L will provide FDNW with the inputs to be integrated in the Section 6.0 of the PSE (See section A.3.3, PSE Requirements). In addition, the analysis techniques, approaches, etc, must be reasonably consistent with those used to develop the TWRS 
HNF-2153, Rev. 0

BIO and FSAR. Proposed exceptions shall be communicated to the Licensing Engineer prior to implementation.

\section{A.3.1 General}

Scope of the PSE: The PSE supports the conceptual design report (CDR) and is submitted as part of the budget validation package for the project. It is required to identify the preliminary facility hazard categorization, the basis for that categorization, and a preliminary hazard and accident analysis. It constitutes a preliminary applicable hazard baseline document used for design, and cost and schedule estimates. As the PSE includes a preliminary Facility Hazard Categorization, it shall be reviewed and approved by $R L$ as a safety basis for the project which is submitted with the CDR package per compliance with HNF-PRO-705, Safety Basis Planning, Documentation, Review and Approval. The PSE is not an authorization basis document and will not be used as part of the TWRS Unreviewed Safety Question (USQ) process.

Purpose of the PSE: The PSE is an aid to RL and the contractor in ensuring major safety considerations (technical and compliance-related) are incorporated early in the project life cycle. The PSE identifies nuclear safety issues and formulates preliminary findings in order to evaluate whether the current concept can provide for safe near surface disposal of solidified low activity waste in accordance with all applicable U.S Department of Energy (DOE) Orders and guidance documents. The PSE is not intended to supersede the need for a formal safety analysis as required in DOE Order 5480.23. The PSE outcome will not finalize or confirm safety systems, but will suggest a list of candidates for safety systems, structures, and components (SSCs) to be further specified during the detailed design phase.

The results of the PSE need to include a preliminary list of Safety Functions consistent and commensurate with the status of the design (i.e, shielding preliminary design and strategy, criticality control principles, confinement principles, material at risk limitations, etc). The PSE should also provide, when relevant, a preliminary list of candidates for TSRs as well as a preliminary Safety Equipment List (Safety Class and Safety Significant SSCs). In most cases the PSE is not expected to go beyond the functional level and will serve as input to the preliminary and detailed design for specific design criteria of the systems. The requirements relating to Natural Phenomena Hazards (i.e, list of the equipment to be earthquake resistant, external flooding mitigation, wind, snow, and ash loads, etc.) will be listed as part of the PSE for use in evaluating technical design choices, and estimating cost and schedule impacts for those choices. HNF-PRO-97, Engineering Design and Evaluation, guidance will be followed to assess the adequacy of the design with the performance categories resulting from the safety analysis.

In addition, the PSE should present the future radiation exposure control strategy given that related design decisions could have a significant impact on the design (larger distances between the sources and the operators, remote controlled operation, shielding addition, work duration limitation, etc).

\section{A.3.2 Responsibilities}

See Table A-1 
HNNF-2153, Rev. 0

This task requires close co-ordination with the ongoing conceptual design effort. Formal monthly coordination meetings are to be set up with the project and design authorities to account for the conceptual design progress and any changes in technical design options. The meetings will also discuss specific PSE findings that may have an impact on the design as well as issues and bases for the selection of the technical design options. Between formal meetings, FDNW safety analysts should expect frequent informal communication with the TWRS NS\&L Licensing Engineer.

Documentation distribution for comments: Drafts of the Preliminary Hazard Analysis, Facility Hazard Categorization, Accident Analysis and of the PSE will be provided for information, as they are developed (e.g.; during monthly status meetings), to the TWRS NS\&L Licensing Engineer. FDNW will also provide a first draft of the complete PSE to the TWRS NS\&L Licensing Engineer for pre-review prior to the PHMC contractor functional review. It is furthermore expected that the FDNW Safety Analysts will provide timely review of the CD documents for consistency with the PSE.

A specific kick-off meeting will be convened to discuss the content of this statement of work prior to preparation and submittal of FDNW's proposal. 
Table A-1 Tasks List for FDNW Cost Estimating

\begin{tabular}{|c|c|c|c|c|}
\hline TASK/DELIVERABLES & INTERFACE NOTES & $\begin{array}{l}\text { DELIVERABLE } \\
\text { RESPONSIBILITY }\end{array}$ & $\begin{array}{l}\text { ESTIMATED } \\
\text { DURATION } \\
\text { (Workdays) }\end{array}$ & $\begin{array}{l}\text { FDNW } \\
\text { RESOURCES }\end{array}$ \\
\hline $\begin{array}{l}\text { 1- Prepare and submit Work Plan for the } \\
\text { PSE }\end{array}$ & $\begin{array}{l}\text { Work Plan to be based } \\
\text { on PHMC contractor } \\
\text { SOW specific to the } \\
\text { PSE }\end{array}$ & $\begin{array}{l}\text { FDNW safety } \\
\text { analysis group }\end{array}$ & $\begin{array}{l}\text { To be provided by } \\
\text { FDNW during } \\
\text { kick-off meeting }\end{array}$ & $\begin{array}{l}\text { To be } \\
\text { provided by } \\
\text { FDNW during } \\
\text { kick-off } \\
\text { meeting }\end{array}$ \\
\hline $\begin{array}{l}\text { 2- Collection of existing project (i.e., AGA, } \\
\text { DRD, etc) documentation and relevant } \\
\text { background documentation }\end{array}$ & $\begin{array}{l}\text { Numatec will aid } \\
\text { FDNW safety analysis } \\
\text { group in collection of } \\
\text { information }\end{array}$ & N/A & $\begin{array}{l}\text { To be provided by } \\
\text { FDNW in PSE } \\
\text { Work Plan }\end{array}$ & $\begin{array}{l}\text { To be } \\
\text { provided by } \\
\text { FDNW in } \\
\text { PSE Work } \\
\text { Plan } \\
\end{array}$ \\
\hline 3- Preliminary Hazard Analysis & $\begin{array}{l}\text { FDNW safety analysis } \\
\text { group + PHA team } \\
\text { including project Cog. } \\
\text { Engineer and process } \\
\text { Engineers and TWRS } \\
\text { NS\&L Rep. }\end{array}$ & $\begin{array}{l}\text { FDNW safety } \\
\text { analysis group } \\
\text { (must provide } \\
\text { facilitation for PHA } \\
\text { meetings) }\end{array}$ & $"$ & $"$ \\
\hline 4- Facility Hazard Categorization & $\begin{array}{l}\text { TWRS NS\&L and } \\
\text { Numatec Project team } \\
\text { need to concur }\end{array}$ & $\begin{array}{l}\text { FDNW safety } \\
\text { analysis group }\end{array}$ & $"$ & $"$ \\
\hline 5- Accident Analysis & $\mathrm{N} / \mathrm{A}$ & $\begin{array}{l}\text { FDNW safety } \\
\text { analysis group }\end{array}$ & '" & $"$ \\
\hline $\begin{array}{l}\text { 6- Identification of candidates for safety } \\
\text { controls and design features }\end{array}$ & $\mathrm{N} / \mathrm{A}$ & $\begin{array}{l}\text { FDNW safety } \\
\text { analysis group }\end{array}$ & $"$ & $"$ \\
\hline
\end{tabular}




\begin{tabular}{|c|c|c|c|c|}
\hline TASK/DELIVERABLES & INTERFACE NOTES & $\begin{array}{l}\text { DELIVERABLE } \\
\text { RESPONSIBILITY }\end{array}$ & $\begin{array}{l}\text { ESTIMATED } \\
\text { DURATION } \\
\text { (Workdays) } \\
\end{array}$ & $\begin{array}{l}\text { FDNW } \\
\text { RESOURCES }\end{array}$ \\
\hline $\begin{array}{l}\text { 7- FDNW PEER and HEDOP review of the } \\
\text { PSE }\end{array}$ & N/A & $\begin{array}{l}\text { FDNW safety } \\
\text { analysis group }\end{array}$ & $"$ & $"$. \\
\hline $\begin{array}{l}\text { 8- PSE first draft (Rev. 0A) delivered for } \\
\text { TWRS NS\&L pre-review }\end{array}$ & $\begin{array}{l}\text { TWRS NS\&L pre- } \\
\text { review for document } \\
\text { quality and compliance } \\
\text { with procedures and } \\
\text { SOW }\end{array}$ & $\begin{array}{l}\text { FDNW safety } \\
\text { analysis group }\end{array}$ & $\begin{array}{l}1 \text { week duration } \\
\text { for TWRS NS\&L } \\
\text { pre-review }\end{array}$ & N/A \\
\hline 9- Finalize PSE draft (Rev. OB) text & N/A & $\begin{array}{l}\text { FDNW safety } \\
\text { analysis group }\end{array}$ & $\begin{array}{l}\text { To be provided by } \\
\text { FDNW in PSE } \\
\text { Work Plan }\end{array}$ & $\begin{array}{l}\text { To be } \\
\text { provided by } \\
\text { FDNW in } \\
\text { PSE Work } \\
\text { Plan } \\
\end{array}$ \\
\hline $\begin{array}{l}\text { 10- PSE draft (Rev. 0B) delivery to TWRS } \\
\text { NS\&L for functional review }\end{array}$ & $\begin{array}{l}\text { TWRS NS\&L will } \\
\text { take care of the } \\
\text { distribution and will } \\
\text { co-ordinate the } \\
\text { functional review } \\
\text { process }\end{array}$ & $\begin{array}{l}\text { FDNW safety } \\
\text { analysis group }\end{array}$ & $"$ & $"$ \\
\hline $\begin{array}{l}\text { 11- Tier I functional review process per } \\
\text { HNF-IP-0842, Volume IV, Section 5.10, } \\
\text { Attachment B }\end{array}$ & $\begin{array}{l}\text { Tier I reviewers from } \\
\text { FDH, LMHC, } \\
\text { Numatec and DE\&SH }\end{array}$ & P.J. Mouette & 2 weeks & N/A \\
\hline
\end{tabular}




\begin{tabular}{|c|c|c|c|c|}
\hline TASK/DELIVERABLES & INTERFACE NOTES & $\begin{array}{l}\text { DELIVERABLE } \\
\text { RESPONSIBILITY }\end{array}$ & $\begin{array}{l}\text { ESTIMATED } \\
\text { DURATION } \\
\text { (Workdays) }\end{array}$ & $\begin{array}{l}\text { FDNW } \\
\text { RESOURCES }\end{array}$ \\
\hline $\begin{array}{l}\text { 12-Disposition of comments from Tier I } \\
\text { functional review }\end{array}$ & $\begin{array}{l}\text { Co-ordinated by P. J. } \\
\text { Mouette, Licensing } \\
\text { Engineer }\end{array}$ & $\begin{array}{l}\text { FDNW safety } \\
\text { analysis group }\end{array}$ & 2 weeks & $\begin{array}{l}\text { To be } \\
\text { provided by } \\
\text { FDNW in } \\
\text { PSE Work } \\
\text { Plan }\end{array}$ \\
\hline $\begin{array}{l}\text { 13- Submit comment disposition to Tier I } \\
\text { reviewers and finalize PSE text (Rev. 0). } \\
\text { FDNW delivers final PSE product to TWRS } \\
\text { NS\&L for approval. }\end{array}$ & $\begin{array}{l}\text { Received by } \\
\text { P.J.Mouette, } \\
\text { Licensing Engineer }\end{array}$ & $\begin{array}{l}\text { FDNW safety } \\
\text { analysis group }\end{array}$ & 1 week & $"$ \\
\hline 14- Preparation of transmittal letter to FDH & $\begin{array}{l}\text { Prepared by P.J. } \\
\text { Mouette }\end{array}$ & $\begin{array}{l}\text { Approved by C.E. } \\
\text { Leach }\end{array}$ & 1 week & N/A \\
\hline $\begin{array}{l}\text { 15- TRWS NS\&L final check of the PSE } \\
\text { package }\end{array}$ & N/A & C.E. Leach & 5 days & N/A \\
\hline 16- TWRS NS\&L approval & N/A & $\begin{array}{l}\text { T.C. Geer, C.E. } \\
\text { Leach, G.A. Gault }\end{array}$ & 3 days & N/A \\
\hline $\begin{array}{l}\text { 17- TWRS Technical Operations and } \\
\text { Engineering release of the PSE }\end{array}$ & N/A & M.A. Payne & 2 days & N/A \\
\hline
\end{tabular}




\section{A.3.3 PSE Requirements}

The PSE format and content shall be compliant with Appendix A of HNF-PRO-703. The analysis techniques and approaches must be reasonably consistent with those used to develop the TWRS BIO and FSAR. The PSE is to be issued as part of the Conceptual Design Package as an Appendix to the Conceptual Design Report (CDR). Discussions about certain sections of the PSE are provided below:

1.0 Introduction and Summary

- $\quad$ Overview of the significant conclusions in the PSE.

- $\quad$ Facility hazard categorization and basis (could refer to a separate supporting document)

\subsection{Design Criteria}

This section will refer to the Design Requirement Document (DRD) and to the Alternative Generation Analysis (AGA) from Burbank 1997 for general requirements and will present, specify and discuss any additional requirements resulting from the safety analysis. Topics to be addressed include, but are not limited to:

- A preliminary list for Safety Class and Safety Significant functions referring to section 4.0 of DOE-STD-3009-94.

- An evaluation of the non Design Basis Accident Nuclear Safety requirements, nuclear safety-related design criteria, and other safety criteria to be used in the design and construction. This should include considerations for facility worker safety, defense-in-depth, external radiation exposure (outside of the building), structural loading criteria, and fire protection basis.

- Design codes, standards, regulations, and DOE Orders which are required for establishing the safety basis of the future near surface disposal facility.(e.g., 10 CFR 61)

3.0 Hazardous Inventories and Assumptions

- Radioactive and hazardous material inventory

- Assumptions coming from existing project documentation

- $\quad$ Assumptions made during the safety analysis process (engineering judgments)

\subsection{Accident Evaluation}

- $\quad$ Preliminary Hazard Analysis development by a multi-disciplinary team

- Accident analysis: Quantitative estimate of accident consequences and frequency are to be prepared when pertinent and made possible by the design status. No credit should be taken for potential mitigative or prevention features already integrated in the design for other purposes. The PSE should evaluate the 
adequacy of the design to assure the safety function based on unprevented and unmitigated accident consequences.

- Comparison to the risk evaluation guidelines: The risk evaluation guidelines to be applied are those set forth in the TWRS BIO.

\subsection{Construction Risk}

- Identify risk to existing nearby facilities from construction.

6.0 Safety Documentation (Inputs will be provided by TWRS NS\&L to FDNW for preparation of this section)

- Identification of additional safety documentation required.

- Proposal for the upcoming Authorization Basis documentation and licensing strategy.

\subsection{Project Interfaces}

- Identify facilities, activities or design features which interface with the proposed project (e.g, Private contractors, TWRS, transportation).

- Identify the risk to the new facility from adjacent facilities.

- Identify the risk to existing facilities from the project.

8.0 Items Requiring Further Resolution.

- Identify issues related to safety, health, and the environment that must be resolved during the design, construction and start up phases and before start of operation.

- Define all design uncertainties related to safety.

- $\quad$ Provide the path forward for resolution of uncertainty.

- Identify and discuss the level of conservatism applied to the assumptions made for the definition of the accident scenarios, the source terms, dose calculations, etc, in order to identify the safety margins and the drivers for these margins.

\section{$9.0^{\circ}$ References}

\section{A.4 Schedule}

The PSE work is to be started at the same time the conceptual design starts and shall be completed (functional review and TWRS NS\&L approval and release) by September 14, 1998. The detailed schedule, to be completed in FDNW Work Plan, is provided below in Table A-2. 
HNF-2153, Rev. 0

Table A-2 Schedule of Deliverables

\begin{tabular}{|c|c|c|}
\hline TASK/DELIVERABLES & Start & Finish \\
\hline 0- PSE development and approval & $\begin{array}{l}\text { To be provided by } \\
\text { FDNW in the PSE } \\
\text { Work Plan }\end{array}$ & $9 / 14 / 98$ \\
\hline $\begin{array}{l}\text { 1- Prepare and submit Work Plan for the } \\
\text { PSE }\end{array}$ & TBD & $\begin{array}{l}3 / 27 / 98 \text { ( } 1 \text { week } \\
\text { after CDR Work } \\
\text { Plan is submitted })\end{array}$ \\
\hline $\begin{array}{l}\text { 2- Collection of existing project (i.e., AGA, } \\
\text { DRD, etc) documentation and relevant } \\
\text { background documentation }\end{array}$ & $\begin{array}{l}\text { To be provided by } \\
\text { FDNW in the PSE } \\
\text { Work Plan }\end{array}$ & $\begin{array}{l}\text { To be provided by } \\
\text { FDNW in the PSE } \\
\text { Work Plan }\end{array}$ \\
\hline 3- Preliminary Hazard Analysis & $"$ & " \\
\hline 4- Facility Hazard Categorization & $"$ & $"$ \\
\hline 5- Accident Analysis & $"$ & $"$ \\
\hline $\begin{array}{l}\text { 6- Identification of candidates for safety } \\
\text { controls and design features }\end{array}$ & $"$ & $"$ \\
\hline $\begin{array}{l}\text { 7- FDNW PEER and Hedop review of the } \\
\text { PSE + comments resolution }\end{array}$ & $"$ & $"$ \\
\hline $\begin{array}{l}\text { 8- PSE first draft (Rev. 0A) delivered to } \\
\text { TWRS NS\&L for pre-review }\end{array}$ & $"$ & $"$ \\
\hline 9- Finalize PSE draft (Rev. 0B) text & $"$ & $"$ \\
\hline $\begin{array}{l}\text { 10- PSE draft (Rev. 0B) delivery to TWRS } \\
\text { NS\&L for functional review }\end{array}$ & $"$ & $"$ \\
\hline $\begin{array}{l}\text { 11- Tier I functional review process per } \\
\text { HNF-IP-0842, Volume IV, Section } 5.10 \text {, } \\
\text { Attachment B }\end{array}$ & $"$ & $"$ \\
\hline $\begin{array}{l}\text { 12- Disposition of comments from Tier I } \\
\text { functional review }\end{array}$ & $"$ & $"$ \\
\hline $\begin{array}{l}\text { 13- Submit comment disposition to Tier I } \\
\text { reviewers and finalize PSE text. FDNW } \\
\text { delivers final PSE product to TWRS NS\&L } \\
\text { for approval. }\end{array}$ & $"$ & $8 / 28 / 98$ \\
\hline 14- Preparation of transmittal letter to FDH & $8 / 31 / 98$ & $9 / 14 / 98$ \\
\hline $\begin{array}{l}\text { 15- TRWS NS\&L final check of the PSE } \\
\text { package }\end{array}$ & $8 / 31 / 98$ & $9 / 14 / 98$ \\
\hline
\end{tabular}


HNF-2153, Rev. 0

\begin{tabular}{||l|l|l||}
\hline \multicolumn{1}{|c|}{ TASK/DELIVERABLES } & \multicolumn{1}{|c|}{ Start } & \multicolumn{1}{c|}{ Finish } \\
\hline 16- TWRS NS\&L approval & $9 / 7 / 98$ & $9 / 9 / 98$ \\
\hline $\begin{array}{l}\text { 17- TWRS Technical Operations and } \\
\text { Engineering release }\end{array}$ & $9 / 10 / 98$ & $9 / 14 / 98$ \\
\hline
\end{tabular}


HNF-2153, Rev. 0

\section{A.5 SAFETY REFERENCES}

HNF-PRO-705, Rev.0, October 1997, "Safety Basis Planning, Documentation, Review and Approval"

DOE Order 5480.23, Nuclear Safety Analysis Reports

DOE-STD-3009-94, Guidance for Preparation of Nuclear Safety Analysis Reports

HNF-PRO-97, Rev.0, Engineering Design and Evaluation

HNF-PRO-703, Rev.0, Safety Analysis Process-New Project

HNF-PRO-704, Rev.0, Hazard and Accident Analysis process

HNF-IP-0842, Volume IV, Section 5.10, Rev.1, LMHC TWRS Administration Manual

10 CFR 61, Licensing Requirements for Land Disposal of Radioactive Waste, Code of Federal Regulations

HNF-SD-WM-BIO-001, Rev. 0I, Tank Waste Remediation System Basis for Interim Operation 


\section{DISTRIBUTION SHEET}

\begin{tabular}{|c|c|c|c|c|c|}
\hline \multirow{2}{*}{$\begin{array}{l}\text { To } \\
\text { Distribution }\end{array}$} & \multirow{2}{*}{\multicolumn{3}{|c|}{$\begin{array}{l}\text { From } \\
\text { W. W. Pickett }\end{array}$}} & \multicolumn{2}{|l|}{ Page 1 of 1} \\
\hline & & & & \multicolumn{2}{|c|}{ Date $04 / 30 / 98$} \\
\hline \multicolumn{4}{|c|}{ Project Title/Work Order } & \multicolumn{2}{|c|}{ EDT No. 624113} \\
\hline \multicolumn{4}{|c|}{$\begin{array}{l}\text { Conceptual Design Statement of Work For The Immobilized Low- } \\
\text { Activity Waste Disposal Facility. Project W-520 }\end{array}$} & \multicolumn{2}{|l|}{ ECN No. } \\
\hline \multicolumn{2}{|c|}{ Name } & $\begin{array}{l}\text { Text } \\
\text { With All } \\
\text { Attach. }\end{array}$ & Text Only & $\begin{array}{l}\text { Attach./ } \\
\text { Appendix } \\
\text { Only }\end{array}$ & $\begin{array}{l}\text { EDT/ECN } \\
\text { Only }\end{array}$ \\
\hline
\end{tabular}

Duke Enqineering and Services Hanford
C. E. Leach
R1-49
$x$

Fluor Daniel Hanford

D. J. Ashley

Fluor Daniel Northwest. Inc.

T. A. Cartson

H6-37 $\quad X$

W. W. Pickett

H6-37

$x(5)$

Lockheed Martin Hanford Corporation

J. F. Bores

G3-21

G3-21

H. L. Boston

H7 -07

S. D. Brumley

H6-37

K. C. Burgard

G3-21

D. L. Burt

H7 -07

L. N. Cortez

G3-21

P. A. Craig

H7- 07

L. R. Dunbar

M. D. Ebben

H7 -07

R. J. Murkowski

H6-37

S. M. O'Toole

G3-21

M. A. Payne

R2-58

R. W. Root

H6-12

G3-21

W. T. Thompson

H6-37

J. A. Voogd

H7 -07

$x$

R. F. Wood

Numatec Hanford Corporation

J. Alibert

S2-48

H5-61

M. Cremonini

$\mathrm{R} 1-49$

P. Mouette

H6-37

$x$
$x$
$x$
$x$
$x$
$x$
$x$

C. A. Petersen

H6-08

Project Files (2)

Central Files

B1-07

$$
\begin{aligned}
& x \\
& X \\
& X \\
& X
\end{aligned}
$$

